\title{
Hypercalcaemia of malignancy and basic research on mechanisms responsible for osteolytic and osteoblastic metastasis to bone
}

\author{
$G$ A Clines and T A Guise
}

Division of Endocrinology and Metabolism, Department of Medicine, University of Virginia, PO Box 801419, Charlottesville, Virginia 22908-1419, USA

(Requests for offprints should be addressed to T A Guise; Email: tag4n@virginia.edu)

\begin{abstract}
Calcium homeostasis is a tightly regulated process involving the co-ordinated efforts of the skeleton, kidney, parathyroid glands and intestine. Neoplasms can alter this homeostasis indirectly through the production of endocrine factors resulting in humoral hypercalcaemia of malignancy. Relatively common with breast and lung cancer, this paraneoplastic condition is most often due to tumour production of parathyroid hormone-related protein and ensuing increased osteoclastic bone resorption. Although control of hypercalcaemia is generally successful, the development of this complication is associated with a poor prognosis. The metastasis of tumour cells to bone represents another skeletal complication of malignancy. As explained in the 'seed and soil' hypothesis, bone represents a fertile ground for cancer cells to flourish. The molecular mechanisms of this mutually beneficial relationship between bone and cancer cells are beginning to be understood. In the case of osteolytic bone disease, tumour-produced parathyroid hormone-related protein stimulates osteoclasts that in turn secrete tumour-activating transforming growth factor- $\beta$ that further stimulates local cancer cells. This 'vicious cycle' of bone metastases represents reciprocal bone/ cancer cellular signals that likely modulate osteoblastic bone metastatic lesions as well. The development of targeted therapies to either block initial cancer cell chemotaxis, invasion and adhesion or to break the 'vicious cycle' is dependent on a more complete understanding of bone metastases. Although bisphosphonates delay progression of skeletal metastases, it is clear that more effective therapies are needed. Cancer-associated bone morbidity remains a major public health problem, and to improve therapy and prevention it is important to understand the pathophysiology of the effects of cancer on bone. This review will detail scientific advances regarding this area.
\end{abstract}

Endocrine-Related Cancer (2005) 12 549-583

\section{Introduction}

Cancer adversely affects bone and mineral metabolism through a broad spectrum of mechanisms. While focal osteolysis at sites of metastases is the most common skeletal manifestation of cancer, systemic effects such as hypercalcaemia or diffuse osteopenia are common. As early as 1889 , Stephen Paget recognized the diversity of effects, stating that in a cancer of the breast the bones suffer in a special way, which cannot be explained by any theory of embolism alone ... the same thing is seen much more clearly in those cases of cancer of the thyroid body where secondary deposition occurs in bones with astonishing frequency.' $\mathrm{He}$ further observed 'A general degradation of the bones sometimes occurs in carcinoma of the breast, yet without any distinct deposition of cancer in them.' These were prescient observations, as it is now recognized that cancer affects bone both by direct metastatic invasion and through systemic humoral mechanisms.

Primary bone tumours make up a small minority of bone-related malignancy. This review will therefore 
focus on the mechanisms by which extra-skeletal cancers affect bone: (1) directly through secondary spread of tumour to bone both by local extension and by distant metastasis and (2) indirectly through elaboration of factors that act to disrupt normal calcium homeostasis at the level of the kidney, bone, or both.

Each of the three most common human neoplasms - breast, prostate and lung - is strongly associated with skeletal morbidity. In the USA alone, it is estimated that in 2004 there would be 217440 new cases of breast cancer and 230110 new cases of prostate cancer resulting in 40580 and 29900 deaths respectively. At the same time, the combined number of lung cancers for males and females was estimated to be 173770 with 160440 deaths (Jemal et al. 2004). The majority of patients dying from these cancers will have bony involvement either through metastatic spread or as a result of systemic tumour-produced factors. Clearly, cancer-associated bone morbidity remains a major public health problem. To improve therapy and prevention it is important to understand the pathophysiology of the effects of cancer on bone. This review will attempt to detail scientific advances regarding this area.

\section{Normal bone remodelling and calcium homeostasis}

\section{Bone remodelling}

A thorough understanding of the normal mechanisms of bone and calcium homeostasis is necessary to appreciate how perturbations in these mechanisms cause hypercalcaemia of malignancy, as well as osteolytic and osteoblastic lesions. Unlike any other canceraffected tissue, bone is being constantly remodelled as a result of the co-ordinated actions of bone-forming osteoblasts and bone-resorbing osteoclasts. This remodelling is highly influenced by both circulating systemic hormones and local bone-derived growth factors. Bone is made up of two physically and biologically distinctive structures: the hard, mineralised matrix of cortical bone and the more metabolically active cancellous or trabecular bone. Cortical bone makes up $85 \%$ of the total bone mass and is found primarily in the long bones of the appendicular skeletal. Trabecular bone, which makes up the remaining $15 \%$, is most predominant in the vertebral bodies and pelvis. Within trabecular bone is the multicellular bone marrow. This space harbours stromal and haematopoietic stem cells with the capacity to differentiate and form osteoblasts and osteoclasts respectively. These cells secrete cytokines and growth factors that have either direct actions on neighbouring cells or become immobilised within the mineralised matrix (Yoneda 1996). Thus, the mineralised matrix is a rich source of insulin-like growth factors (IGFs)-I and II, transforming growth factor- $\beta$ (TGF $\beta$ ), platelet-derived growth factors (PDGFs) and bone morphogenetic proteins (BMPs) (Hauschka et al. 1986, Mohan \& Baylink 1991). These growth factors, however, are unable to bind to their receptors until released from the matrix as a result of osteoclastic bone resorption (Pfeilschifter $\&$ Mundy 1987), a component of the bone remodelling process.

Recent insights into the interaction of marrow stromal cells of osteoblastic lineage with osteoclasts have provided a better understanding of the mechanisms regulating osteoclast activation and bone resorption. Osteoclastogenesis is a stromal cell and osteoblast-dependent process that is mediated by the receptor activator of nuclear factor $\kappa \mathrm{B}$ (RANK)/ RANK ligand (RANKL)/osteoprotegerin (OPG) system. Stromal and osteoblast cell expression of the membrane-bound RANKL (Lacey et al. 1998) is increased by a number of stimuli, most notable parathyroid hormone (PTH). The receptor for this ligand, RANK, is a high-affinity receptor of osteoclast precursors, as well as $\mathrm{T}$ and $\mathrm{B}$ cells, fibroblasts and dendritic cells (Anderson et al. 1997). When unopposed, RANKL binds RANK and induces osteoclast formation in the presence of Macrophage (M)-colony stimulating factor (M-CSF) (Lacey et al. 2000). OPG, a member of the tumour necrosis factor (TNF) receptor superfamily, is a secreted RANKL decoy receptor of osteoblastic-lineage cells (Simonet et al. 1997, Yasuda et al. 1998). OPG achieves its effect on osteoclasts indirectly by binding to, and blocking the effect of RANKL (Lacey et al. 1998). It therefore appears that OPG competes with RANK for association with RANKL and that the ratio of OPG/RANKL is a determinate of osteoclast development. The expression of OPG and RANKL is modulated by a variety of osteotrophic factors, as will be discussed in subsequent sections.

\section{Calcium homeostasis}

Serum calcium concentration is highly regulated by a complex system of calcitropic hormones with actions at the levels of bone, kidney and gut (Fig. 1). PTH and the biologically active form of vitamin $\mathrm{D}$ (calcitriol or 1,25-dihydroxyvitamin $\left.\mathrm{D}\left(1,25-(\mathrm{OH})_{2} \mathrm{D}_{3}\right)\right)$ act on these organs to keep blood ionized calcium levels remarkably stable. Serum calcium concentration is 
Calcium Fluxes in a Normal Adult

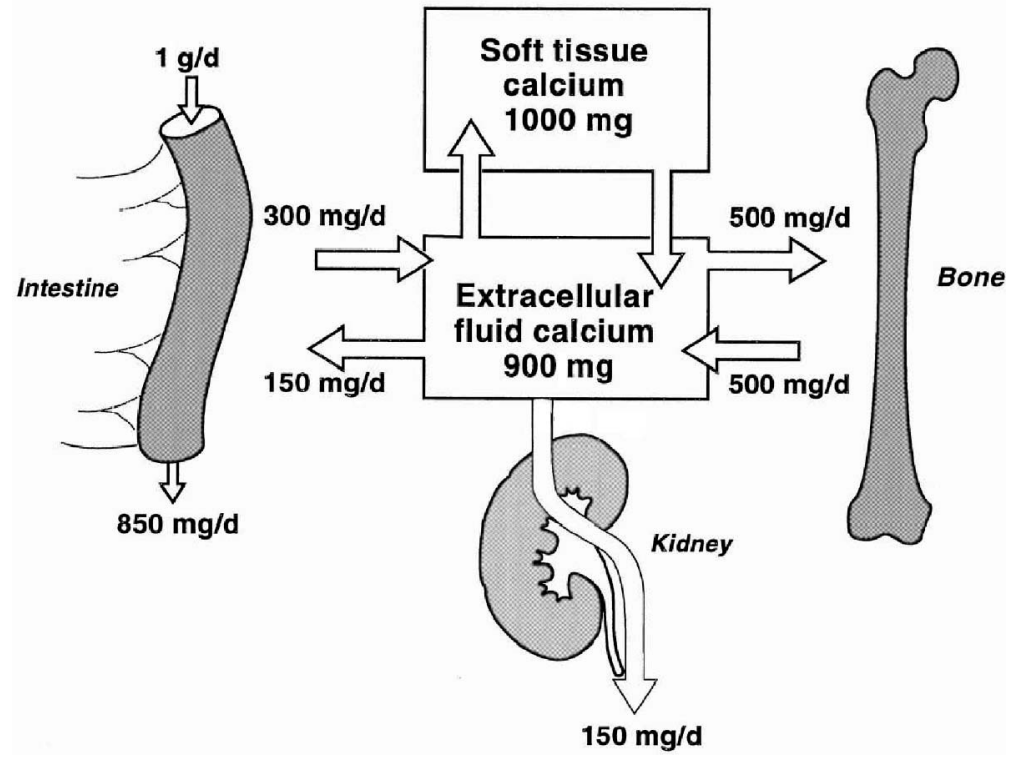

Figure 1 Calcium homeostasis for a normal adult in zero calcium balance. The numbers are estimates of the amount of calcium exchanged between the extracellular fluid and gut, kidney and bone each day. The exchange system between bone fluid and the extracellular fluid is not taken into account. (Adapted from Mundy (1995)). d, day.

maintained within a very narrow range by the interplay of these two calcitropic hormones with their target tissues of bone, kidney and gut. Under normal conditions, the net exchange of calcium from extracellular fluid to these organs remains at zero balance. PTH and vitamin D are the most physiologically relevant calcitropic hormones in humans, while calcitonin plays a much lesser role. Normal calcium homeostasis has been extensively reviewed (Mundy \& Guise 1999). Since most skeletal manifestations of malignancy involve pathways intrinsic to PTH or vitamin $\mathrm{D}$ action, these will be further reviewed here.

\section{PTH}

PTH is an 84 amino acid polypeptide that is secreted by the chief cells of the parathyroid glands. Regulation of secretion is highly dependent on the ionized calcium concentration in the extracellular fluid. Serum PTH concentration decreases as the ionized calcium concentration increases, representing a simple negative feedback loop. In 1993, the calcium-sensing receptor $(\mathrm{CaR})$ that mediates this feedback loop was cloned from bovine parathyroid cells (Brown et al. 1993). CaR is a member of the $G$ protein-coupled receptor family. Activation of this receptor ultimately leads to a down-regulation of PTH at the post-transcriptional level (Moallem et al. 1998, Moz et al. 2002). In addition to ionized calcium, calcitriol is a potent inhibitor of PTH secretion (Silver et al. 1986, Okazaki et al. 1988) and hyperphosphataemia increases PTH secretion (Moallem et al. 1998, Tatsumi et al. 1998).

The biological actions of PTH include: (1) stimulation of osteoclastic bone resorption, (2) stimulation of calcium reabsorption and inhibition of phosphate reabsorption from renal tubules and (3) stimulation of renal $1 \alpha$-hydroxylase resulting in production of 1,25 $(\mathrm{OH})_{2} \mathrm{D}_{3}$, which increases intestinal absorption of calcium and phosphate. These actions result in an increased serum calcium and increased urinary phosphate excretion. PTH actions are mediated through binding of the amino terminus of the PTH molecule to the PTH receptor, a member of the family of $G$ protein-coupled receptors that contain seven transmembrane-spanning domains (Juppner et al. 1991). The ligand-bound PTH receptor activates adenylate cyclase, through the activation of $G$ protein $G \alpha s$, producing cAMP while activating protein kinase A. Although the majority of the PTH signal appears to be transduced through this pathway, the phospholipase $\mathrm{C} /$ protein kinase $\mathrm{C}$ system also contributes to $\mathrm{PTH}$ signal transduction (Mahon et al. 2002, Swarthout et al. 2002). 
Table 1. Defences against hypocalcaemia and hypercalcaemia

\begin{tabular}{lll}
\hline Organ & \multicolumn{1}{c}{ Hypocalcaemia } & \multicolumn{1}{c}{ Hypercalcaemia } \\
\hline Parathyroid & $\uparrow P T H$ secretion & $\downarrow \mathrm{PTH}$ secretion \\
Kidney & $\downarrow \mathrm{GFR} \rightarrow \downarrow$ filtered $\mathrm{Ca}++\uparrow \mathrm{Ca}++$ reabsorption & $\uparrow \mathrm{GFR} \rightarrow \uparrow$ filtered $\mathrm{Ca}++\downarrow \mathrm{Ca}++$ reabsorption \\
& $\uparrow 1,25(\mathrm{OH})_{2} \mathrm{D}_{3}$ & $\downarrow 1,25(\mathrm{OH})_{2} \mathrm{D}_{3}$ \\
Gastrointestinal tract & $\uparrow \mathrm{Ca}++$ absorption & $\downarrow \mathrm{Ca}++$ absorption \\
Skeleton & $\uparrow$ Bone resorption & $\downarrow$ Bone resorption \\
\hline
\end{tabular}

GFR, glomerular filtration rate

\section{$1,25-(\mathrm{OH})_{2} \mathrm{D}_{3}$}

Another important hormone involved in calcium homeostasis is calcitriol or $1,25-(\mathrm{OH})_{2} \mathrm{D}_{3}$ - a major biologically active metabolite of the vitamin $\mathrm{D}$ sterol family. Vitamin D precursor is either ingested in the diet or synthesized in the skin from 7-dehydrocholesterol through exposure to sunlight. Hydroxylation occurs in the liver at the $\mathrm{C}-25$ position to form 25-hydroxyvitamin $\mathrm{D}\left(25-(\mathrm{OH}) \mathrm{D}_{3}\right)$, the precursor of the more potent metabolite, $1,25-(\mathrm{OH})_{2} \mathrm{D}_{3} .25-(\mathrm{OH}) \mathrm{D}_{3}$ is hydroxylated at the $\mathrm{C}-1$ position in the kidney by $1 \alpha$-hydroxylase, a complex cytochrome P450 mitochondrial enzyme system located in the proximal nephron (Kawashima et al. 1982), to form 1,25$(\mathrm{OH})_{2} \mathrm{D}_{3}$ (Norman et al. 1982, Bell 1985). The renal $1 \alpha$-hydroxylation of $25-(\mathrm{OH}) \mathrm{D}_{3}$ is the major recognized control point of vitamin D metabolism, responding to phosphate, PTH and calcitriol concentrations. PTH and low serum phosphate concentrations independently increase $1,25-(\mathrm{OH})_{2} \mathrm{D}_{3}$ production (Portale et al. 1989, Brenza \& DeLuca 2000). Vitamin D receptors within renal proximal convoluted tubule cells are involved in an autocrine negative feedback loop, whereby increased levels of $1,25-(\mathrm{OH})_{2} \mathrm{D}_{3}$ will down-regulate $1,25-(\mathrm{OH})_{2} \mathrm{D}_{3}$ production (Takeyama et al. 1997). Other known important extra-renal sites of $1,25-(\mathrm{OH})_{2} \mathrm{D}_{3}$ production are the placenta and granulomatous tissue (Barbour et al. 1981, Gkonos et al. 1984, Zerwekh \& Breslau 1986).

$1,25-(\mathrm{OH})_{2} \mathrm{D}_{3}$ increases plasma calcium and phosphate concentrations by increasing the absorption of calcium and phosphate from the gastrointestinal tract. It also increases bone resorption (Holtrop et al. 1981) and enhances the capacity for PTH to promote renal tubular calcium reabsorption in the nephron. It is a powerful differentiation agent for committed osteoclast precursors (Takahashi et al. 1988, Suda et al. 1992), causing their maturation to multinucleated cells that are capable of resorbing bone. Thus, 1,25$(\mathrm{OH})_{2} \mathrm{D}_{3}$ ensures a supply of calcium and phosphate available at bone surfaces for the mineralization of bone matrix. Deficiency of either $1,25-(\mathrm{OH})_{2} \mathrm{D}_{3}$ or $1 \alpha$-hydroxylase results in osteomalacia or rickets.

\section{Calcitonin}

In the case of calcitonin, its precise biological role in the overall scheme of calcium homeostasis is uncertain. Calcitonin directly inhibits osteoclastic bone resorption, and the effect is rapid, occurring within minutes of administration (Friedman et al. 1968). This inhibition is accompanied by the production of cAMP (Heersche et al. 1974), as well as an increase in cytosolic calcium (Moonga et al. 1992) in the osteoclasts, resulting in contraction of the osteoclast cell membrane (Chambers \& Magnus 1982). These effects are transient and probably have little role in chronic calcium homeostasis.

\section{Defences against hypercalcaemia and hypocalcaemia}

The normal physiological defences against hypercalcaemia and hypocalcaemia are listed in Table 1. The majority of these defence mechanisms are mediated through the hormonal actions of PTH and 1,25$(\mathrm{OH})_{2} \mathrm{D}_{3}$. Although the role of endogenous calcitonin is relatively modest in comparison with $\mathrm{PTH}$ and 1,25$(\mathrm{OH})_{2} \mathrm{D}_{3}$, pharmacological calcitonin therapy can be beneficial, as discussed later.

In general, these hormonal actions are more effective in protecting against hypocalcaemia than hypercalcaemia. Perturbations in these mechanisms, as exemplified by excessive increases in bone resorption, deficiencies or excesses of PTH or $1,25-(\mathrm{OH})_{2} \mathrm{D}_{3}$, and defects in renal capacity to handle calcium and phosphate, will result in either hypercalcaemia or hypocalcaemia.

\section{Hypercalcaemia}

Hypercalcaemia is defined as total serum calcium, adjusted for protein concentration, above $10.2 \mathrm{mg} / \mathrm{dl}$, although the upper limit of normal can vary depending 
Table 2. Clinical features of hypercalcaemia (Mundy \& Martin 1982)

\begin{tabular}{ll}
\hline $\begin{array}{l}\text { Neurologic and } \\
\text { psychiatric }\end{array}$ & $\begin{array}{l}\text { Lethargy, drowsiness, confusion, } \\
\text { disorientation, disturbed sleep, } \\
\text { nightmares, irritability, depression, } \\
\text { hypotonia, decreased deep tendon } \\
\text { reflexes, stupor, coma } \\
\text { Anorexia, vomiting, constipation, } \\
\text { peptic ulceration, acute pancreatitis } \\
\text { Arrhythmias, synergism with digoxin, } \\
\text { hypertension }\end{array}$ \\
Renal & $\begin{array}{l}\text { Polyuria, polydipsia, hypercalciuria, } \\
\text { nephrocalcinosis, impaired } \\
\text { glomerular filtration }\end{array}$ \\
\hline
\end{tabular}

on the laboratory. Ionised calcium is a more precise measure of calcium concentration, the normal plasma concentrations ranging from 1.12 to $1.23 \mathrm{mmol} / 1$ (Favus 2003). However, measurement of total serum calcium, when adjusted for serum albumin, is sufficient for most situations. With the advent of automated biochemical testing, hypercalcaemia is now recognized to be more common than once realized. By far, the most common causes of hypercalcaemia are primary hyperparathyroidism $\left(1^{\circ} \mathrm{HPT}\right)$ and malignancy.

The clinical features of hypercalcaemia are featured in Table 2. Neuromuscular, gastrointestinal and renal manifestations are most common. Optimal neurological function is dependent on extracellular calcium level and symptoms can range from subtle neuropsychiatric manifestations, such as irritability and depression, to muscle weakness, delirium and even coma (LeBoff \& Mikulec 2003). Non-specific gastrointestinal symptoms of anorexia, constipation, nausea and vomiting may predominate. Hypercalcaemia causes an impaired ability of the distal nephron to concentrate urine and is an important part of the differential diagnosis for nephrogenic diabetes insipidus. Symptoms may vary in individual patients and are related both to the absolute concentration of serum calcium and to the rate of rise in serum calcium. Severe hypercalcaemia is likely the result of a vicious cycle. The hypercalcaemic effects of anorexia, nausea, vomiting and impaired renal concentrating ability lead to dehydration and, subsequently, altered mental status. This, in turn, may promote immobilization and lead to worsening hypercalcaemia. In addition to the symptoms of hypercalcaemia, clinical features of hypercalcaemia of malignancy include signs and symptoms of the underlying cancer. Generally, the cancer is well advanced when hypercalcaemia occurs, and the prognosis is poor. Survival beyond 6 months is uncommon (Ralston et al. 1990).
Table 3. Malignancies associated with hypercalcaemia (Mundy \& Martin 1982)

\begin{tabular}{lc}
\hline Malignancy & Frequency (\%) \\
\hline Lung & 35 \\
Breast & 25 \\
Haematologic & 14 \\
Head and neck & 6 \\
Renal & 3 \\
Prostate & 3 \\
Unknown primary & 7 \\
Others & 7 \\
\hline
\end{tabular}

\section{Hypercalcaemia of malignancy}

Malignancy is the most common cause of hypercalcaemia in the hospitalized patient, and malignancyassociated hypercalcaemia is one of the more common paraneoplastic syndromes. Up to $30 \%$ of patients with cancer may develop hypercalcaemia during the course of their disease (Grill \& Martin 2000). The relative frequencies of malignancies associated with hypercalcaemia are listed in Table 3 (Mundy \& Martin 1982). Hypercalcaemia occurring in the setting of malignancy may be due to (1) humoral factors secreted by tumours that act systemically on target organs of bone, kidney and intestine to disrupt normal calcium homeostasis, (2) local factors secreted by tumours in bone, either metastatic or haematological, which directly stimulate osteoclastic bone resorption and (3) coexisting $1^{\circ} \mathrm{HPT}$.

The first two of these situations should be viewed as opposite ends of a continual spectrum, rather than as completely unrelated pathologies. Clearly the pathophysiology of hypercalcaemia in patients with solid tumours and no bone metastases at one end of the spectrum, and myeloma associated with extensive local bone destruction adjacent to the tumour cells at the other, is very different. However, in between these extremes are hypercalcaemic patients with squamous cell carcinomas in which hypercalcaemia may occur with some, but not extensive, osteolytic bone metastases, and hypercalcaemic patients with advanced breast carcinoma in whom hypercalcaemia almost never occurs in the absence of extensive osteolytic bone destruction. Separating hypercalcaemia into subcategories based on the assumption that the underlying mechanisms are distinct is not entirely satisfactory. This is because the mediators may be identical, except that in one situation it is a local mediator while in another it is a humoral mediator. Additionally, if the tumour burden in bone is great, local tumourproduced mediators of bone resorption may be 
present in sufficient quantities to have systemic effects. Although this review will discuss the effects of cancer on bone organised into such categories, it is important to understand that a significant portion of cancer patients will fall into the middle of this spectrum, having both humoral and local effects of tumour on bone.

\section{Humoral mediators of hypercalcaemia of malignancy}

\section{Parathyroid hormone-related protein (PTHrP)}

Hypercalcaemia has been associated with malignancy since the development of serum calcium assays in the 1920s. Only in 1941, however, did Fuller Albright advance the hypothesis that PTH is ectopically produced by certain tumour types. Over the subsequent five decades investigators determined that PTH was not, in fact, the cause of humoral hypercalcaemia of malignancy (HHM), but that a 'PTH-like factor' was responsible for most cases. In 1987, this PTHrP was purified from human lung cancer (Moseley et al. 1987), breast cancer (Burtis et al. 1990) and renal cell carcinoma (Strewler et al. 1987) simultaneously by several independent groups and cloned shortly thereafter (Suva et al. 1987).

PTHrP shares $70 \%$ sequence homology with PTH over the first 13 amino acids at the $\mathrm{N}$-terminus. Beyond the initial amino-terminal sequence the protein is unique and shows no further sequence homology with PTH. The cloned PTHrP protein is larger than PTH and three distinct isoforms of 139, 141 and 173 amino acids have been described. Similarly, the human PTHrP gene is much larger and more complex than the PTH gene, spanning $15 \mathrm{~kb}$ of genomic DNA and having nine exons and three promoters. Despite these differences, both PTH and PTHrP bind to a common $\mathrm{PTH} / \mathrm{PTHrP}$ receptor (Abou-Samra et al. 1992) and share similar biological activities (Horiuchi et al. 1987).

PTHrP has been detected in a variety of tumour types as well as in normal tissue (Danks et al. 1989, Asa et al. 1990). The widespread expression of PTHrP in normal tissue was the first evidence that the hormone had a role in normal physiology. In addition to the PTH-like effects, emerging work testifies to the fact that PTHrP plays a role in (1) the regulation of cartilage differentiation and bone formation (Minina et al. 2001), (2) the growth and differentiation of skin (Wysolmerski et al. 1994b), mammary gland (Wysolmerski et al. 1998) and teeth (Philbrick et al. 1998), (3) cardiovascular function (Schluter \& Piper 1998), (4) transepithelial calcium transport in mammary epithelia and placenta (Wysolmerski et al. 1994a,
Kovacs et al. 1996), (5) relaxation of smooth muscle in uterus, bladder, arteries and ileum (Thiede et al. 1990, Yamamoto et al. 1992, Botella et al. 1994, Pirola et al. 1994) and (6) host immune function (Funk et al. 1994, 1995). Normal subjects do not have detectable circulating levels of PTHrP, suggesting that in normal physiology PTHrP acts as a local regulator or cytokine in the tissues where it is produced.

Approximately $80 \%$ of hypercalcaemic patients with solid tumours have detectable or increased plasma concentrations of PTHrP (Burtis et al. 1990). In addition to the diverse normal physiological functions of PTHrP, it has a multifunctional role in cancer as well. Such identified functions include (1) mediating hypercalcaemia, (2) aiding in the development and progression of osteolytic bone metastasis, as will be discussed in subsequent sections, (3) regulating growth of cancer cells (Luparello et al. 1993, 1995, Li et al. 1996) and (4) acting as a cell survival factor (Chen et al. 2002a). The first identified consequence of PTHrP in cancer was the HHM syndrome.

HHM vs $1^{\circ} H P T$. Despite similarities between the syndromes of HHM and $1^{\circ} \mathrm{HPT}$ and the similar biological activities of PTHrP and PTH respectively, unexplained differences between these syndromes exist. First, patients with PTHrP-mediated HHM have low 1,25- $(\mathrm{OH})_{2} \mathrm{D}_{3}$ levels compared with patients with $1^{\circ} \mathrm{HPT}$, even though both hormones stimulate $1 \alpha$-hydroxylase activity (Schilling et al. 1993). Moreover, infusion of PTH or PTHrP in healthy volunteers over a 48 -h period increased plasma $1,25-(\mathrm{OH})_{2} \mathrm{D}_{3}$ levels; however, PTH was more effective than PTHrP (Horwitz et al. 2003). Secondly, while both syndromes have marked increases in osteoclastic bone resorption, many patients with HHM do not have the normally coupled increase in osteoblastic activity that those with $1^{\circ} \mathrm{HPT}$ experience. Studies using either serum markers of bone turnover (Nakayama et al. 1996) or quantitative bone histomorphometry (Stewart et al. 1982) have demonstrated this uncoupling of bone resorption from bone formation. Finally, unlike the metabolic acidosis seen in patients with $1^{\circ} \mathrm{HPT}$, patients with HHM often have a metabolic alkalosis with a low plasma chloride and high plasma bicarbonate concentration. Although many explanations have been postulated for the discrepancies between HHM and $1^{\circ} \mathrm{HPT}$, such as the pulsatile secretion of PTH and the apparent continuous secretion of PTHrP and biologically active PTHrP fragment (Plawner et al. 1995) and suppression of bone formation and $1 \alpha$-hydroxylase activity by other tumour-associated 
factors, the reasons for these differences have not been adequately elucidated.

PTHrP in hypercalcaemia associated with breast cancer. The role of PTHrP in breast cancer-associated hypercalcaemia deserves special consideration. Breast cancer predominantly affects bone through metastatic mechanisms, typically with lytic deposits in the skeleton. Approximately $10 \%$ of women with breast cancer will have hypercalcaemia as a complication at some point in the disease. The association of hypercalcaemia with extensive osteolytic lesions in breast cancer is so strong that the presentation of hypercalcaemia without bone metastases should suggest the presence of coexistent $1^{\circ} \mathrm{HPT}$ (Fierabracci et al. 2001). Based on this association, it was long held that breast cancer-associated hypercalcaemia results from excessive reabsorption of bone around tumour deposits. However, clinical studies (Ralston et al. 1990) failed to demonstrate any relationship between the extent of bone metastasis and serum calcium levels. Conversely, studies exploring the potential role for a humoral mediator of hypercalcaemia in breast cancer clearly demonstrated altered renal handling of calcium and phosphate, as well as increased nephrogenous cAMP, suggesting that $10-60 \%$ of hypercalcaemic patients with breast cancer had a circulating factor with PTHlike properties. The identification of PTHrP as this factor is hardly surprising when it is recalled that PTHrP appears to play an important role in normal breast physiology. In the case of breast cancer, PTHrP appears to have both paracrine and endocrine actions.

PTHrP was detected by immunohistochemical staining in $60 \%$ of 102 invasive breast tumours removed from normocalcaemic women, but not in normal breast tissue (Southby et al. 1990). At least four other studies have confirmed these percentages, and one of these has demonstrated immunoreactive PTHrP within the cytoplasm of lobular and ductal epithelial cells in normal and fibrocystic breast tissues (Bundred et al. 1991, 1992, Liapis et al. 1993, Kohno et al. 1994). Furthermore, $65-92 \%$ of hypercalcaemic breast cancer patients (with and without bone metastasis) had detectable plasma PTHrP concentration by radioimmunoassay similar to those documented in patients with HHM due to non-breast tumours (Bundred et al. 1991, Grill et al. 1991). PTHrP is an important mediator of hypercalcaemia in breast cancer. It also plays a significant role in the pathophysiology of breast cancer metastasis to bone, as evidenced by clinical studies indicating that PTHrP expression by primary breast cancer is more commonly associated with the development of bone metastasis and hypercalcaemia
(Bundred et al. 1992). This topic will be discussed in a later section.

PTHrP in hypercalcaemia associated with haematologic malignancies. Hypercalcaemia associated with haematologic malignancies results both from systemic effects of tumour-produced factors such as 1,25$(\mathrm{OH})_{2} \mathrm{D}_{3}$ (discussed below), and from secretion of local bone-active cytokines, such as interleukin (IL)-6, IL-1 and lymphotoxin or TNF $\beta$, from tumour in bone. PTHrP has been demonstrated to be an important pathogenic factor in the development of hypercalcaemia in some patients with haematologic malignancies. In a clinical study of 76 patients with various haematological malignancies, $50 \%$ of the 14 hypercalcaemic patients had significant increases in plasma PTHrP concentrations (Kremer et al. 1996). Of these, five had non-Hodgkin's lymphoma, one had Hodgkin's disease and one had multiple myeloma. The serum $1,25-(\mathrm{OH})_{2} \mathrm{D}_{3}$ concentrations, when measured, were low in the hypercalcaemic non-Hodgkin's lymphoma patients who had increased plasma PTHrP concentrations. Also of interest in this study is the fact that several normocalcaemic patients with nonHodgkin's lymphoma, Hodgkin's lymphoma, multiple myeloma and Waldenstrom's macroglobulinaemia had increased plasma PTHrP concentrations as measured by an amino-terminal PTHrP assay. Using a sensitive two-site immunoradiometric assay, other investigators have noted increased plasma PTHrP concentrations in patients with adult $\mathrm{T}$ cell leukaemia and $\mathrm{B}$ cell lymphoma (Ikeda et al. 1994). Finally, in separate studies, circulating concentrations of PTHrP, comparable with those in HHM, were present in two of four hypercalcaemic patients with non-Hodgkin's lymphoma, in three of nine with myeloma and in a patient with myeloid blast crisis of chronic myeloid leukaemia (Seymour et al. 1993, Firkin et al. 1996). Thus, the humoral mediators in the hypercalcaemia associated with haematological malignancies include both $1,25-(\mathrm{OH})_{2} \mathrm{D}_{3}$ and PTHrP.

\section{$1,25-(\mathrm{OH})_{2} \mathrm{D}_{3}$}

Under normal physiological conditions, serum calcium concentration and levels of $1,25-(\mathrm{OH})_{2} \mathrm{D}_{3}$ are inversely related. In the setting of hypercalcaemia, serum 1,25$(\mathrm{OH})_{2} \mathrm{D}_{3}$ concentrations are suppressed unless there is persistent stimulation of $1 \alpha$-hydroxylase activity from an autonomous source of PTH, such as with $1{ }^{\circ} \mathrm{HPT}$. Outside of this situation, lack of $1,25-(\mathrm{OH})_{2} \mathrm{D}_{3}$ suppression indicates abnormal regulation of 1,25$(\mathrm{OH})_{2} \mathrm{D}_{3}$ synthesis and further suggests extra-renal production such as that observed with granulomatous 
disease. In granulomatous disease, activated macrophages within the granuloma synthesise $1,25-(\mathrm{OH})_{2} \mathrm{D}_{3}$ (Adams et al. 1983, Gkonos et al. 1984, Mason et al. 1984). Similarly, a major mediator of hypercalcaemia in Hodgkin's disease, non-Hodgkin's lymphoma and other haematological malignancies appears to be an extra-renal production of $1,25-(\mathrm{OH})_{2} \mathrm{D}_{3}$ (Seymour et al. 1994). In this scenario, hypercalcaemic patients have increased plasma $1,25-(\mathrm{OH})_{2} \mathrm{D}_{3}$ concentrations with low or normal plasma PTH and urinary cAMP concentrations (Rosenthal et al. 1985), without the presence of bone involvement. Affected patients have also been shown to have increased fasting urinary calcium excretion (Rosenthal et al. 1985), as well as increased intestinal calcium $\left({ }^{47} \mathrm{Ca}\right)$ absorption (Breslau et al. 1984). Increased $1,25-(\mathrm{OH})_{2} \mathrm{D}_{3}$ concentrations were noted in 12 of 22 hypercalcaemic patients with non-Hodgkin's lymphoma. In addition, 71\% of 22 normocalcaemic patients with non-Hodgkin's lymphoma were hypercalciuric, and $18 \%$ had increased serum $1,25-(\mathrm{OH})_{2} \mathrm{D}_{3}$ concentrations. These findings led the investigators to conclude that disregulated 1,25$(\mathrm{OH})_{2} \mathrm{D}_{3}$ production was common in patients with diffuse large cell lymphoma (Seymour et al. 1994). The low serum PTH and urinary cAMP concentrations indicated that neither PTH nor PTHrP mediated the hypercalcaemia in this setting. Prostaglandins, when measured, have been low, and selected patients had no calcium-lowering effect from indomethacin therapy (Firkin et al. 1996).

Thus, the mechanisms responsible for hypercalcaemia in this setting appear to be multifactorial and include $1,25-(\mathrm{OH})_{2} \mathrm{D}_{3}$-mediated increases in intestinal absorption of calcium and osteoclastic bone resorption. Additionally, many of the reported patients had altered renal function, a finding that suggests that impaired renal calcium clearance may also be contributing to the hypercalcaemia in certain patients. It is likely that the lymphoma tissue itself hydroxylates $25-(\mathrm{OH}) \mathrm{D}_{3}$ to the active $1,25-(\mathrm{OH})_{2} \mathrm{D}_{3}$ similar to the situation in hypercalcaemia associated with granulomatous disease. One $\alpha$-hydroxylase activity has been demonstrated in human $\mathrm{T}$ cell lymphotrophic virus type-I-transformed lymphocytes as well as in other extra-renal tissues (Fetchick et al. 1986, Zehnder et al. 2001). None of the reported patients with 1,25$(\mathrm{OH})_{2} \mathrm{D}_{3}$-mediated hypercalcaemia had concomitant granulomatous disease, and hypercalcaemia often improved with medical or surgical therapy that resulted in a decrease in serum $1,25-(\mathrm{OH})_{2} \mathrm{D}_{3}$ concentration. Recurrence of hypercalcaemia and increased plasma $1,25-(\mathrm{OH})_{2} \mathrm{D}_{3}$ concentrations have been documented with recurrence of disease (Mercier et al. 1988).

\section{PTH}

For many years after Fuller Albright's observations in 1941 malignancy-associated hypercalcaemia was attributed to ectopic tumour-produced PTH. It is now clear that PTHrP is responsible in the great majority of cases of HHM. There have been rare cases, however, of authentic tumour-produced PTH causing hypercalcaemia. Specifically, ectopic PTH production has been documented in a small cell carcinoma of the lung (Yoshimoto et al. 1989), a squamous cell carcinoma of the lung (Nielsen et al. 1996), an ovarian cancer (Nussbaum et al. 1990), a widely metastatic primitive neuroectodermal tumour (Strewler et al. 1993), a papillary adenocarcinoma of the thyroid (Iguchi et al. 1998) and a thymoma (Rizzoli et al. 1994). Molecular analysis of the ovarian carcinoma revealed both DNA amplification and rearrangement in the upstream regulatory region of the PTH gene. Interestingly, the primitive neuroectodermal tumour produced both PTH and PTHrP that resulted in severe hypercalcaemia. These reported patients did not have coexisting $1^{\circ} \mathrm{HPT}$ since the parathyroid glands were normal at the time of neck exploration or at autopsy in all cases. However, the fact remains that ectopic production of PTH is a rare event, and it is clearly documented that most patients with malignancy-associated hypercalcaemia have suppressed plasma PTH concentrations (Stewart et al. 1980). It should be emphasised that the most likely cause of hypercalcaemia in the setting of malignancy that is associated with a normal or increased serum PTH concentration is co-existing hyperparathyroidism.

\section{Other tumour-associated factors}

There is accumulating evidence that solid tumours may produce other humoral factors, either alone or in combination with PTHrP, that have the capacity to stimulate osteoclastic bone resorption and cause hypercalcaemia. These factors include IL-1, IL-6, TGF $\alpha$, TNF and granulocyte CSF (G-CSF). Administration of IL-1 injections to mice caused a mild hypercalcaemia (Sabatini et al. 1988, Boyce et al. 1989), which has been effectively blocked by an IL-1 receptor antagonist (Guise et al. 1993). Mice bearing Chinese hamster ovarian $(\mathrm{CHO})$ tumours transfected with the cDNA for IL-6 developed mild hypercalcaemia (Black et al. 1991), as did mice bearing a renal carcinoma that co-secreted IL-6 and PTHrP (Weissglas et al. 1995). High serum levels of IL-6 in patients with HHM have also been reported (Barhoum et al. 1999, Ueno et al. 2000).

Human TGF $\alpha$ and TNF $\alpha$ stimulated osteoclastic bone resorption in vitro and resulted in hypercalcaemia 
in vivo (Ibbotson et al. 1985, Bertolini et al. 1986, Yates et al. 1992). TNF $\alpha$ also caused hypercalciuria, without an increase in nephrogenous cAMP, and increased osteoclastic bone resorption in vivo in a mouse model (Johnson et al. 1989). In addition, as noted in the previous section, some of these factors have been shown to modulate the end-organ effects of PTHrP on bone and kidney. In some instances, factors such as TGF $\alpha$, IL-1, IL-6 and TNF enhanced the hypercalcaemic effects of PTHrP. The ability of IL-6 to enhance PTHrP-mediated hypercalcaemia appeared to be due to increased production of the early osteoclast precursors by IL-6 (as measured by granulocyte macrophage colony-forming units), in combination with increased production of the more committed osteoclast precursors by PTHrP (Hulter et al. 1985).

Prostaglandins of the E series are powerful stimulators of bone resorption (Klein \& Raisz 1970), although their role in bone destruction associated with malignancy remains unclear (Mundy 1995). Some of the effects of cytokines on bone may be mediated in part through prostaglandins. Indomethacin, a prostaglandin synthesis inhibitor, has been shown to block part of the osteoclast-stimulatory effects of IL-1 in vivo (Sabatini et al. 1988, Boyce et al. 1989). Although prostaglandins have been demonstrated to be produced by cultured tumour cells in vitro, indomethacin treatment of malignancy-associated hypercalcaemia is only occasionally effective (Mundy et al. 1983). Thus, it is unlikely that prostaglandins have a major causal role in hypercalcaemia associated with malignancy.

\section{Treatment of hypercalcaemia of malignancy}

The ultimate treatment of malignancy-associated hypercalcaemia is eradication of the underlying cancer. However, cure is frequently not possible, and in patients with symptomatic or life-threatening hypercalcaemia therapy must be aimed specifically against the mediating mechanisms. Increased osteoclastic bone resorption is present in essentially every patient with hypercalcaemia of malignancy and is, therefore, a key target for treatment and prevention of hypercalcaemia. Two of these mechanisms in particular, increased osteoclastic bone absorption and increased renal tubular calcium reabsorption, are common to most patients with hypercalcaemia of malignancy, even those cases not associated with PTHrP production (Tuttle et al. 1991). Medical therapy is, therefore, aimed at inhibiting bone resorption and promoting renal calcium excretion. As many hypercalcaemic patients are dehydrated at presentation, the latter can be effectively addressed with intravenous administration of isotonic saline. This first step of therapy serves to rehydrate the patient while enhancing calciuresis by increasing the glomerular filtration rate and reducing the fractional reabsorption of calcium and sodium. The use of loop diuretics, such as furosemide, to enhance calcium excretion is frequently overemphasised in clinical practice. These agents may exacerbate fluid loss; therefore, their use should be limited to the volume-repleted patient and only then with close monitoring of volume status (Suki et al. 1970). Hydration alone rarely results in full resolution of hypercalcaemia (Hosking et al. 1981), however, and more aggressive therapies are usually needed.

Bisphosphonates are currently the mainstay for long-term treatment of hypercalcaemia and osteolytic bone disease. They have an affinity for bone surfaces undergoing active resorption and are released in the bone microenvironment during remodelling. These compounds decrease osteoclastic bone resorption by two described mechanisms. First, the nitrogensubstituted bisphosphonates, such as alendronate, risedronate and zoledronic acid, are potent inhibitors of the enzyme farnesyldiphosphate synthase, thereby blocking protein isoprenylation. It is believed that the prenylation of small GTP-binding proteins is important for structural integrity of the osteoclast; without it, the osteoclasts undergo apoptosis. Secondly, the non-nitrogen-containing bisphosphonates, clodronate and etidronate, are less potent and also induce osteoclastic apoptosis but by a different mechanism. These bisphosphonates are metabolically incorporated into non-hydrolyzable ATP analogues that inhibit ATP-dependent intracellular enzymes. The bisphosphonates have been known to inhibit osteoclastic bone resorption for over 30 years.

There are also several lines of evidence that suggest bisphosphonates effect osteoclastic bone resorption indirectly through actions on osteoblasts. For example, bisphosphonates have previously been shown to have multiple actions on osteoblasts such as (1) modulation of proliferation and differentiation (Reinholz et al. 2000), (2) prevention of apoptosis (Plotkin et al. 1999), (3) modulation of extracellular matrix protein production (Giuliani et al. 1998b, Klein et al. 1998), (4) regulation of the expression and excretion of IL-6 (Giuliani et al. 1998a, Tokuda et al. 1998) and (5) decrease of angiogenesis (Green \& Clezardin 2002, Wood et al. 2002). Recently, Viereck et al. (2002) presented in vitro evidence that bisphosphonates act directly on human osteoblasts to increase the production of both OPG mRNA and protein. Clearly, the implication is that by increasing OPG expression, 
the RANKL-mediated stimulation of osteoclasts can be neutralised.

The various bisphosphonates available on the market vary in potency, but all are poorly absorbed from the gut and are most effective for treatment of hypercalcaemia when used intravenously. Intravenous etidronate, the least potent of its class, normalized calcium concentration in $30-40 \%$ of patients when given in doses of $7.5 \mathrm{mg} / \mathrm{kg}$ on 3 consecutive days (Kanis et al. 1987, Singer et al. 1991, Gucalp et al. 1992). Oral etidronate, at dosages of $25 \mathrm{mg} / \mathrm{kg}$ per day for more than 6 months can cause bone mineralization defects (Fleisch 1991). Pamidronate, alternatively, combines high potency with low toxicity and has become the agent of choice for the treatment of hypercalcaemia of malignancy. When used in the recommended doses of $30-90 \mathrm{mg}$ i.v. over $4-24 \mathrm{~h}$, it is highly effective in normalizing serum calcium concentrations and is not associated with mineralization defects. The onset of clinically apparent action is somewhat delayed with the bisphosphonates. Clinical studies using $90 \mathrm{mg}$ infusion of pamidronate over $4 \mathrm{~h}$ indicate that the mean time to achieve normocalcaemia is approximately 4 days, while the mean duration of normocalcemia is 28 days (Purohit et al. 1995). An effective method for achieving a rapid and sustained reduction in serum calcium concentration is to use pamidronate in combination with calcitonin. The combined use of a bisphosphonate with calcitonin lowers serum calcium levels more rapidly and effectively than either alone (Thiebaud et al. 1990).

Zoledronic acid, the most potent bisphosphonate available, has been recently approved for the treatment of hypercalcaemia of malignancy. At a dose of $4 \mathrm{mg}$ and $8 \mathrm{mg}$, this bisphosphonate was compared with a single infusion of pamidronate $(90 \mathrm{mg})$ in patients with hypercalcaemia of malignancy. Zoledronic acid was superior in respect to response rates, time to calcium normalization and response duration (Major et al. 2001). The $4 \mathrm{mg}$ dose is Federal Drug Administration approved, as renal dysfunction occurred with the $8 \mathrm{mg}$ dose.

Inhibiting osteoclastic bone resorption and renal tubular calcium reabsorption within minutes of administration, calcitonin also makes an excellent agent for the acute treatment of hypercalcaemia. Unfortunately, tachyphylaxis frequently develops within $48 \mathrm{~h}$ as a result of down-regulation of the calcitonin receptor. Concomitant use of glucocorticoids, however, can prolong the effective time of treatment (Binstock \& Mundy 1980). This effect appears to result from a glucocorticoid-mediated up-regulation of cell-surface calcitonin receptors and increased de novo production of calcitonin receptors in the osteoclast (Wada et al. 2001). Calcitonin can be administered every $6-12 \mathrm{~h}$ in doses of $4-8 \mathrm{U} / \mathrm{kg}$. Human calcitonin is available but salmon calcitonin is generally used. If salmon calcitonin is used, then a test dose of $1 \mathrm{U}$ should be administered first, since rare anaphylactic reactions have been reported.

Two anti-neoplastic agents have been used effectively for the treatment of malignancy-associated hypercalcaemia. Plicamycin, or mithramycin, is an inhibitor of DNA-dependent RNA synthesis and a potent inhibitor of bone resorption. The dosage used to treat hypercalcaemia $(25 \mu \mathrm{g} / \mathrm{kg})$ is one-tenth the usual chemotherapeutic dose and should be infused over $4 \mathrm{~h}$. It has considerable side-effects of nephrotoxicity, hepatotoxicity, thrombocytopenia, nausea and vomiting. Gallium nitrate is another anti-neoplastic agent with calcium-lowering effects. It also has serious nephrotoxicity and is somewhat inconvenient to use as it is administered as a continuous 5-day infusion. Use of these anti-neoplastic agents should be reserved for cases of hypercalcaemia that are unresponsive to maximum doses of bisphosphonates.

Finally, about $30 \%$ of patients treated with glucocorticoids for malignancy-associated hypercalcaemia respond with a fall in serum calcium concentration. Glucocorticoids are most likely to have a clinical effect in the setting of hypercalcaemia associated with multiple myeloma or haematologic malignancies associated with $1,25-(\mathrm{OH})_{2} \mathrm{D}_{3}$. In these situations, glucocorticoids inhibit osteoclastic bone resorption by decreasing tumour production of locally active cytokines in addition to having direct tumorolytic effects (Mundy et al. 1978). Glucocorticoids, in dosage equivalents of $40-60 \mathrm{mg}$ prednisone daily, should be given. If no appreciable response is observed within 10 days, then glucocorticoid therapy should be discontinued.

\section{Metastatic cancer and localised bone destruction}

The potential for tumour metastasis, especially to bone, is greater with certain types of cancers. Lung, breast and prostate cancers all frequently metastasise to bone, and bone metastases are present in nearly all patients with advanced breast or prostate cancer. Bone is the third most common site of metastasis of solid tumours after the liver and the lung. Metastatic bone disease is generally divided into osteoblastic and osteolytic disease, but most cancers lie within a spectrum of these two extremes. Osteolytic metastases 
are much more common, however, and are one of the most feared complications of malignancy. They are usually destructive and are much more likely to be associated with pathological fracture and hypercalcaemia. The consequences for the patient include intractable bone pain at the site of the metastasis, pathologic fracture after trivial injury, nerve compression syndromes due to obstruction of foramina (the most serious example is spinal cord compression) and hypercalcaemia, when bone destruction is advanced. Once tumour cells are housed in the skeleton, curative therapy is no longer possible in most patients and only palliative therapy is available. Tumour cells metastasise most frequently to the axial skeleton, and particularly to the vertebrae, pelvis, proximal ends of the long bones and skull (Galasko 1981). It is clear that there are important properties of both the tumour cell (the seed) and the skeleton (the soil) that determine the likelihood that any particular tumour will metastasise to bone.

The mechanism by which a solitary tumour is able to escape and invade other distant structures is beginning to be understood. Once tumour cells enter the circulation, they traverse vascular organs, including the red bone marrow, where they migrate through wide-channeled sinusoids to the endosteal bone surface. Since hypercalcaemia of breast cancer is associated with extensive bone metastasis in the majority of patients, understanding the mechanism for tumour cell migration to bone and subsequent bone destruction should also clarify the mechanisms by which cancer cells cause hypercalcaemia.

\section{Clinical features}

Bone pain is a frequent cancer-related complication with the spine being a common location of metastasis. As this is often an initial symptom, distinguishing metastatic bone disease from common causes of back pain such as disc disease and muscle strain can be difficult. However, there are warning signs that should alert the physician that the patient's discomfort could be due to a serious condition. Progressive pain in an older individual or a patient with a history of cancer warrants further investigation. One study evaluated the aetiology of back pain in 1975 patients in a primary care setting and discovered that $0.66 \%$ of patients had a malignancy (Deyo \& Diehl 1988). Other worrisome signs and symptoms include age greater than 50 years, weight loss, no relief with bed rest and duration greater than 1 month (Deyo \& Diehl 1988). A patient who is found to have lower extremity motor nerve dysfunction, dysreflexia or loss of bowel or bladder function requires prompt evaluation for cord compression or spinal root impingement (cauda equina syndrome).

Pathological fractures as a result of metastatic bone disease result in acute pain and disability. Vertebral crush fractures will often result in height loss and pain, and can be the initial symptom of bone metastases. Fracture of other weight-bearing bones such as long bones and the hip result in the most disability.

\section{Diagnosis}

The diagnosis of metastatic bone disease often relies on radiographic methods followed by biopsy of the area in question, especially in a patient without an established diagnosis of malignancy. For patients with high clinical suspicion, plain radiographs are indicated for initial evaluation of focal bone pain. Plain films have a reported sensitivity of $60 \%$ and specificity of $99.5 \%$ for diagnosing vertebral metastases (Deyo \& Diehl 1988). Although most lesions are described as either lytic or sclerotic, in reality skeletal metastases are typically mixed, and plain radiographs of affected areas are often abnormal. Radionuclide bone scan can confirm the diagnosis as the nuclear tracer, typically technetium-99, has affinity at sites of active bone formation, whether the sites are lytic or sclerotic. Bone scans are more sensitive than plain films for osteoblastic metastases, because increases in blood flow and bone mineral turnover that are detected by bone scans are evident earlier than radiographic evidence of overt bone remodelling (Jarvik \& Deyo 2002). With the diagnosis of a malignancy that has a predilection for bone, radionucleotide bone scans are the diagnostic test of choice for determining the stage of the disease. Magnetic resonance imaging (MRI) can also be utilised when results of plain films or bone scans are uncertain. They are particularly helpful at imaging soft tissues surrounding suspected bone metastases. The sensitivity of MRI for the diagnosis of spine metastases is $83-93 \%$ with a specificity of $90-97 \%$ (Jarvik \& Deyo 2002). Furthermore, the use of diffusion-weighted and contrast enhancement can accurately differentiate benign from malignant processes (Spuentrup et al. 2001, Chen et al. 2002b). In a patient with suspected cauda equina syndrome, MRI provides excellent views of the vertebral column and spinal cord.

While laboratory studies are unable to diagnose skeletal metastases definitively, several are helpful when monitoring progression in established cases. A marked elevation of alkaline phosphatase in a patient with malignancy would raise the possibility of hepatic or skeletal involvement. An increase in the 
bone-specific alkaline phosphatase would indicate an increase in bone mineral turnover and the likely presence of skeletal metastases. Peptide by-products produced during the formation of collagen are helpful in monitoring osteoporosis therapies and may also be beneficial in monitoring the progression of skeletal metastases. The major organic component of bone matrix is type I collagen. The complex biosynthesis of collagen by the osteoblast releases soluble pro-peptide fragments, which can be assayed as markers of new bone formation and osteoblastic activity. Similarly, osteoclastic bone resorption releases fragments from cross-linked collagen, which can be assayed as markers of bone destruction. These markers can be used to monitor active bone remodelling in patients and their responses to bisphosphonate treatment (Garnero 2001). Bone formation markers include bone-specific alkaline phosphatase and serum procollagen I aminoterminal propeptide, while resorption markers include urinary collagen cross-linked N-telopeptide (NTX), collagen I carboxy-terminal telopeptide, pyridinolines and deoxypyridinolines. Bone formation and resorption markers are often increased in prostate cancer patients with osteoblastic metastases. However, such markers, especially those of resorption, can also be increased as a consequence of bone loss due to androgen deprivation therapy and cannot be used alone to diagnose bone metastases. For example, NTX is not as sensitive as a bone scan for the diagnosis of bone metastases, but may provide an auxiliary diagnostic index for a bone scan (Fukumitsu et al. 2002). There is evidence, however, that markers of bone turnover can aid the clinician in determining the response to therapy (Costa et al. 2002). NTX is the most sensitive in that respect (Berruti et al. 2002).

\section{Basic research on mechanisms responsible for osteolytic and osteoblastic metastasis to bone}

\section{Introduction: Paget's 'seed and soil' hypothesis}

Hypercalcaemia of malignancy clearly conveys a poor prognosis, with survival of less than 3 months (Ralston et al. 1990, Wimalawansa 1994). Most patients with metastatic bone disease fortunately do not have hypercalcaemia and may survive for several years after the first detection of metastatic disease. The morbidity associated with metastasis to bone, however, is high. Bone pain, fracture, nerve compression and hypercalcaemia are common sequelae. Nearly $70 \%$ of women who die of breast cancer have bone metastasis
(Coleman \& Rubens 1987). A large number of patients struggle for years with the complications of bone metastasis and therefore understanding the process is important to improve therapy and prevention. The remainder of this article will focus on the recent developments in our understanding of the mechanisms of osteolytic and osteoblastic lesions.

The process of metastasis is an extremely complex cascade of linked sequential events, each of which must be successfully completed for a tumour cell to establish a secondary tumour in bone.

After growth of a tumour at the primary site, a tumour cell must (1) detach from the primary site, (2) enter the systemic vasculature via the permeable neovasculature of the tumour, (3) survive host immune response and physical forces in the circulation, (4) arrest in a distant capillary bed, (5) escape the capillary bed and (6) proliferate in the metastatic site. Both entry and egress from the vasculature involve similar processes of attachment to the basement membrane, secretion of proteolytic enzymes in order to disrupt the basement membrane and migration through the basement membrane. The attachment of tumour cells to basement membranes and to other cells is mediated through cell adhesion molecules. Inherent tumour cell motility in response to chemotactic stimuli is also an important factor for tumour cell invasion of the secondary site.

Breast cancer is one of a limited number of primary neoplasms that display osteotropism, an extraordinary affinity to grow in bone. This property has provided a key paradigm for our understanding of the metastatic process. Paget, during his observations of breast cancer in 1889 , proposed the 'seed and soil' hypothesis to explain this phenomenon. 'When a plant goes to seed, its seeds are carried in all directions; but they can only grow if they fall on congenial soil.' In essence, the microenvironment of the organ to which the cancer cells metastasise may serve as a fertile soil on which the seeds (or cancer cells) may grow. This century-old concept remains a basic principle of our understanding of cancer metastasis, guiding current progress in the research of molecules produced by bones and tumour cells to enrich the vicious cycle (Chirgwin \& Guise 2000) of secondary tumour growth.

A comprehensive investigation to identify gene products that enhance breast cancer metastatic potential demonstrated that patients who develop metastases possess unique gene expression profile signatures and are predictive of aggressive disease (van't Veer et al. 2002). The gene products found to be overexpressed belong to families that control cell cycling, angiogenesis and invasion. A similar study using gene 
expression profiling was reported but focused on gene products that have a specific role in bone metastasis. The human breast cancer cell line MDA-MB-231 forms osteolytic bone disease when introduced into athymic mice by intracardiac inoculation (Guise 1997). Subpopulations of MDA-MB-231 having a greater osteolytic potential than the parental cell line were isolated by serial passage and gene expression profile comparison with the parental cell line was performed (Kang et al. 2003). Eleven genes were identified that have a greater than fourfold expression pattern in the highly bone metastatic line. Four of these gene products, IL-11, connective tissue growth factor (CTGF), the chemokine receptor CXCR4 and matrix metalloproteinase (MMP)-1 were further analysed. Overexpression of not a single gene but of a combination of two or more in parental MDA-MB-231 enhanced in vivo osteolytic capacity. Thus, these genes that have different functions, i.e. chemotaxis, invasion and osteolysis, co-operate to produce a full bone metastasis potential. None of these genes was represented in a report by van't Veer et al. (2002) involving a gene expression study of primary tumours. This implied that breast cancer cells are capable of developing osteotropic potential rather than possessing inherent ability.

\section{Chemotaxis, invasion and adhesion}

Before establishing a metastatic lesion in bone or tissue, tumour cells must first adhere to extracellular matrix components and other cells. The predilection of certain tumours to metastasise to specific characteristic tissues is likely to be determined by ligand-receptor interactions between specific tumour cell type and target site (Roy \& Mareel 1992). Indeed, experimental evidence supports the assertion that tumour cell surface expression of adhesion molecules mediates targeting to bone with subsequent development of metastasis (Yoneda 2000). A number of molecules have been identified that promote tumour cell escape, including E-cadherin, osteonectin, osteopontin and urokinase. However, the chemokine system, integrins and the MMPs have convincingly been demonstrated to play a more direct role in bone metastasis.

\section{CXCR4}

A study to identify potential chemokine receptors in the migration of breast cancer cells to metastatic sites reported that the chemokine receptor CXCR4 is highly expressed in these cells. Furthermore, the ligand, stromal cell-derived factor-1 (SDF-1 or CXCL12), was found to be present in tissues that represent common sites of metastasis, including bone marrow. Moreover, neutralising antibodies to this receptor impaired metastasis to regional lymph nodes and lung in a mouse model, but bone metastasis was not examined (Muller et al. 2001). The expression of CXCR 4 by breast cancer cells is regulated by other factors. Vascular endothelial growth factor (VEGF) functions as an autocrine factor in breast carcinoma cells and blockade of this signalling pathway decreases the invasiveness of the cancer cells in vitro (Bachelder et al. 2002). The transcription factor nuclear factor- $\kappa \mathrm{B}$ also controls CXCR4 expression by binding its promoter and activating transcription (Helbig et al. 2003). The CXCR4/SDF-1 interaction also acts in the homing to bone in other cancer cell types. CXCR4expressing prostate cancer cell lines exhibited adherence to bone marrow endothelial cells when treated with SDF-1 and migrated across an SDF-1 gradient. This suggests a potential role of this interaction in prostate cancer bone metastasis (Taichman et al. 2002). CXCR4 may also be involved in bone marrow metastasis in neuroblastoma (Geminder et al. 2001).

\section{Integrins}

Bone marrow stromal cells express the vascular cell adhesion molecule-1 (VCAM-1), which is a ligand for $\alpha_{4} \beta_{1}$ integrin (Michigami et al. 2000). Tumour cells expressing $\alpha_{4} \beta_{1}$ integrin should preferentially adhere to bone marrow stromal cells to establish bone metastases. CHO cells transfected with $\alpha_{4} \beta_{1}$ integrin resulted in bone and lung invasion when inoculated intravenously into nude mice compared with lung invasion alone in mice inoculated with non-transfected CHO cells (Matsuura et al. 1996). Moreover, neutralizing antibodies against $\alpha_{4} \beta_{1}$ integrin or VCAM-1 inhibited development of bone metastases. Similar expression of $\alpha_{3} \beta_{1}, \alpha_{6} \beta_{1}$ or $\alpha_{v} \beta_{1}$ integrins did not induce bone metastases.

The $\alpha_{v} \beta_{3}$ integrin receptor that binds the Arg-GlyAsp (RGD) peptide sequence is found on a variety of extracellular matrix proteins, including osteopontin, vitronectin and bone sialoprotein, and appears to be important in homing and, possibly, invasion of tumour cells into the bone endosteum (Sung et al. 1998, Felding-Habermann et al. 2001). Proliferation and adhesion of breast cancer cells appears to be controlled, at least in part, by the integrin $\alpha_{\mathrm{v}} \beta_{5}$ (Sung et al. 1998). Although, prostate carcinoma cells express the integrin $\alpha_{v} \beta_{3}$ and others, antagonists of $\alpha_{v} \beta_{3}$ do not interfere with adhesion and the role of these molecules in prostate carcinoma bone metastases remains unclear (Cooper et al. 2003). 


\section{MMPs}

The MMPs are a family of at least 28 zinc-dependent proteinases that either are bound to the extracellular membrane or secreted within the local environment (Egeblad \& Werb 2002). MMPs participate in the progression of cancer metastases not only by the degradation of matrix leading to invasion, but also by the alteration of signalling molecules affecting tumour growth and migration. This process is manifested through the cleavage of tethered signalling molecules such as IGF-binding protein (IGF-BP)-1, E-cadherin, fibroblast growth factor receptor 1 and pro-TGF $\beta$ (Stamenkovic 2003). MMP function is modulated by at least four tissue inhibitors of metalloproteinases (TIMPs) and $\alpha 2$-macroglobulin. The expression of MMPs has been found to be increased in most cancer types including breast and prostate (Upadhyay et al. 1999, Bachmeier et al. 2001). High levels of MMPs have been associated with poor prognosis (Nakopoulou et al. 2003, Ranuncolo et al. 2003).

MMPs appear to have a specific role in bone metastases. MMP-2 and MMP-9 cleave latent TGF $\beta$ binding protein-1, which may result in the release of TGF $\beta$ stored within the extracellular matrix of bone, thereby promoting cancer cell growth (Dallas et al. 2002). Blockade of MMP-2 activity decreases the invasiveness of breast and prostate cancer cell lines in vitro, possibly by interfering with the binding of bone sialoprotein of cancer cells with extracellular matrix integrin $\alpha_{\mathrm{v}} \beta_{3}$ present within bone (Karadag et al. 2003). MMP-9 increases integrin $\alpha_{v} \beta_{3}$-mediated migration of the breast cancer cell line MDA-MB-435 (Rolli et al. 2003) and neutralising antibodies to MMP-9 decrease the invasive potential of a prostate cancer cell line (Festuccia et al. 1999). Recently, MMP-3 and MMP-7 were reported to cleave cell membrane-associated RANKL to a soluble form resulting in osteoclast activation in an in vitro model, suggesting MMPs have a role in osteolytic bone metastases (Lynch \& Matrisian 2003).

\section{Other factors affecting chemotaxis, invasion and adhesion}

Tumour cells metastasising from a primary site must have the motility to move through the bone marrow sinusoids in order eventually to arrest in bone. Autocrine motility factor (AMF), thymosin $\beta 15$ and heatshock protein 27 (hsp27) have each been implicated as potential factors controlling cell motility (Watanabe et al. 1991, 1996). AMF is the extracellular form of a glycolytic enzyme, phosphoglucose isomerase. It is functionally similar to platelet derived-endothelial cell growth factor (PD-ECGF), in being non-classically secreted and having distinct intracellular and extracellular functions (Jeffery et al. 2000). AMF has species-specific effects on bone cells, dose-dependently stimulating RANKL mRNA and depressing that of OPG in bone marrow stromal cells (Li et al. 2000). In vivo, however, it is not an osteolytic factor but stimulates periosteal bone formation in nude mice. Thymosin $\beta 15$ increases cell motility, and when production was decreased by expression of antisense constructs, metastases were prevented in the Dunning rat prostate adenocarcinoma model (Bao et al. 1996). Similarly, overexpression of hsp27 in MDA-MD-231 cells decreased cell motility in vitro and bone metastasis in mice (Lemieux et al. 1999). Several tumour factors have been described that have autocrine effects on tumour cell motility, including autotaxin (Nam et al. 2001) and AMF (Silletti et al. 1996). The latter is a well-characterised marker of metastatic breast cancer and its mRNA is increased by heregulin (Talukder et al. 2000). Increased activity of the non-receptor kinase c-Src has been associated with a breast cancer aggressiveness in human studies (Verbeek et al. 1996). In animal models, MDA-MB-231 clones with increased expression of c-Src produce larger osteolytic lesions and higher amounts of PTHrP compared with control MDA-MB-231 cells (Myoui et al. 2003). The increased metastatic potential may in part be due to modulation of tumour cell adhesion and motility by c-Src through integrin adhesion and signalling (Playford \& Schaller 2004).

\section{Local tumour syndromes in bone}

Exploration of the pathophysiology of bone metastasis has been hindered by the paucity of animal models of spontaneous bone metastasis. Various techniques of experimental bone metastasis in animals have been developed throughout the years and include injection of tumour cells directly into (1) the intramedullary cavity (Galasko \& Bennett 1976), (2) abdominal aorta (Powles et al. 1973), (3) tail vein with inferior vena cava occlusion (Shevrin et al. 1988), (4) left upper thigh muscle (Kostenuik et al. 1992), (5) left thoracic artery with renal artery occlusion and (6) left cardiac ventricle (Arguello et al. 1988, Nakai et al. 1992).

\section{Osteolytic metastases}

Secondary tumour deposition in bone frequently causes osteolysis or bone destruction at the site of deposition. Breast cancer is the most common tumour type to do so, although prostate, lung, renal cell and thyroid tumours are all associated with osteolytic 
lesions. The following discussion will focus on breast cancer as a model for cancer-mediated osteolysis.

Breast cancer as the 'seed'. The first of these characteristics is the ability to cause the destruction of the hard, mineralized matrix. Breast cancer cells in vitro secrete abundant acid and proteolytic enzymes capable of destroying bone (Eilon \& Mundy 1978). In vivo, however, it appears that tumour cells are not active effectors of bone destruction, particularly during the establishment of metastasis. Histological analysis and scanning electron microscopy of osteolytic bone metastases indicate that osteoclasts adjacent to tumour cells actively resorb bone (Boyde et al. 1986, Taube et al. 1994). This would suggest that breast cancer cells have the ability to stimulate osteoclastic bone resorption. The presence of PTHrP in primary breast tumour has been discussed previously. However, PTHrP expression by breast cancer at metastatic sites differs significantly from expression at the primary site. Retrospective studies of breast cancer metastasis revealed that $90 \%$ of metastases to bone express PTHrP, as compared with only $17 \%$ at non-bone sites and $60 \%$ of primary tumours (Southby et al. 1990, Powell et al. 1991, Vargas et al. 1992), suggesting that expression of PTHrP is a factor that favours metastasis to bone. This strong evidence linking PTHrP to osteolytic metastasis has led to speculation that PTHrP may be the sole factor responsible for osteoclastic activation at sites of secondary breast cancer deposition.

PTHrP as a mediator of osteolysis. Developing the theory of PTHrP as a mediator of osteolysis, Guise et al. (1996) tested the effects of a neutralizing antibody to PTHrP-(1-34) in a mouse model of bone metastasis. Inoculation of the breast cancer cell line MDA-MD231 into the left cardiac ventricle of mice reliably produced osteolytic metastasis. Mice that were pretreated with monoclonal antibody to PTHrP-(1-34) developed significantly fewer and smaller osteolytic lesions than controls. Histomorphometric analysis of long bones of mice treated with the PTHrP antibody revealed significantly fewer osteoclasts at the tumourbone interface and less tumour than controls. Conversely, when MDA-MD-231 cells were engineered to overproduce PTHrP, an increase in the number of osteolytic metastases was seen (Guise et al. 1994). Additionally, when mice with established osteolytic metastases due to MDA-MB-231 were treated with the PTHrP antibody, there was an appreciable decrease in the rate of progression of disease as compared with control (Yin et al. 1995, Guise \& Mundy 1996). Similar findings have been demonstrated in this model using a human lung squamous cell carcinoma (Iguchi et al. 1996). The breast cancer cell line, MCF-7, does not express PTHrP and is not associated with osteolytic lesions. However, when engineered to overexpress PTHrP, MCF-7 cells induced marked bone destruction and increased osteoclast formation as compared with controls (Thomas et al. 1999).

The increased local PTHrP concentration drives RANKL expression and inhibits OPG secretion from osteoblasts and stromal cells, and thereby activates osteoclastogenesis through the RANK located on osteoclast precursors (Thomas et al. 1999). While PTHrP expression by tumour cells within the bone microenvironment results in osteolysis, PTHrP is not the primary factor that leads to the development of bone metastases. Murine mammary cancer cells, a tumour type that ordinarily does not produce PTHrP, overexpress PTHrP and develop hypercalcaemia but not bone metastases (Wysolmerski et al. 2002). Taken together, the data strongly suggest that PTHrP is not important in the establishment of osteolytic bone metastases but is critical in the progression.

Other factors. Tumour cells also produce a number of other important factors that lead to osteolysis. When IL-6, IL-11 and VEGF are secreted by osteolytic breast cancer cell lines following TGF $\beta$ stimulation, they potentiate the effects of PTHrP on osteoclastic bone resorption (de la Mata et al. 1995, Kakonen et al. 2002a). IL-8 production correlates with an increased metastatic potential in MDA-MB-231 cells but appears to be independent of PTHrP secretion (Bendre et al. 2002). Bone-derived factors besides TGF $\beta$ also contribute to this vicious cycle.

Factors opposing osteolysis. Just as tumour cells produce osteolysis-enhancing factors, they also produce other factors rendering the cancer less effective as a seed for metastasis. The breast cancer cell line MDA-MB-231, overexpressing either E-cadherin or TIMP-2, was studied utilising the mouse model of osteolytic metastases. This experiment resulted in a decrease in the development of osteolytic metastases compared with control non-transfected cells (Mbalaviele et al. 1996, Yoneda et al. 1997). Several interleukins, IL-4, IL-12 and IL-18, and interferon- $\gamma$ inhibit osteoclastic bone resorption (Gillespie \& Horwood 1998, Martin et al. 1998, Reddy \& Roodman 1998). IL-18, in particular, has been shown to decrease osteolytic bone metastasis by using MDA-MD-231 cells in the mouse model (Nakata et al. 1999). It remains to be tested 
experimentally, however, whether tumour cells metastatic to bone secrete factors that oppose osteolysis.

Bone microenvironment as the 'soil'. Immobilised within the mineralised bone matrix is a rich trove of growth factors, but the effects of bone-derived factors on tumour cells remain understudied. These growth factors are released from the matrix by osteoclastic bone resorption during the normal course of the physiological bone remodelling required to maintain structural integrity of bone. In addition to the immobilised growth factors within the matrix, cytokines and growth factors are also abundantly produced within the multicellular bone marrow, particularly by stromal and immune cells. Thus, once tumour cells arrest in bone, the high concentrations of cytokines and growth factors in the microenvironment provide a fertile soil in which to grow. The environment is further enriched as the tumour cells stimulate osteoclastic bone resorption, leading to the release of more bone-derived growth factors that enhance survival and growth of the cancer, while simultaneously disrupting normal bone remodelling thus resulting in bone destruction. van der Pluijm et al. (2001) elegantly demonstrated that several mRNAs are increased in bone versus non-bone sites of human breast cancer metastases in nude mice. RNA abundances were determined by species-specific RT-PCR. PTHrP, VEGFs and M-CSF were increased specifically in bone, while several mouse markers of host angiogenesis were similarly increased. These experiments did not identify the factor(s) responsible for the bonespecific mRNA induction.

TGF $\beta$. TGF $\beta$ mobilised from the bone matrix increases metastasis of breast cancer by stimulating tumour production of PTHrP (Yin et al. 1999). Data from a renal cell carcinoma (Zakalik et al. 1992), a squamous cell carcinoma (Kiriyama et al. 1993, Merryman et al. 1994) and the breast cancer cell line MDA-MB-231 (Guise et al. 1994) all suggest that TGF enhances PTHrP production post-transcriptionally, by mRNA stabilization. Pfeilschifter \& Mundy (1987) showed that osteoclastic bone resorption releases TGF $\beta$ in active form. TGF $\beta$ normally stimulates mesenchymal cell proliferation and extracellular matrix biosynthesis, while inhibiting growth of epithelial cells (Massague 1998).

The effects of TGF $\beta$ are mediated through complex receptor interactions (Massague et al. 1997). TGF $\beta$ binds a type II receptor which recruits and phosphorylates a type I receptor in turn. MDA-MB-231 breast cancer cells were transfected with a cDNA encoding a TGF $\beta$ type II receptor lacking a cytoplasmic domain (TßRII $\Delta$ cyt) (Wieser et al. 1993). T $\beta$ RII $\Delta$ cyt binds TGF $\beta$, but is unable to phosphorylate the type I receptor, thus signal transduction is not initiated and this mutant receptor acts in a dominant-negative fashion to block the biological effects of TGF $\beta$ (Wrana et al. 1994). MDA-MB-231 cells so transfected did not increase PTHrP expression in response to TGF $\beta$ stimulation when compared with controls. Similarly, when MDA-MB-231 cells expressing T $\beta$ RII $\Delta$ cyt were inoculated into the left cardiac ventricle of mice, they caused both significantly fewer and significantly smaller osteolytic lesions compared with control cells (Yin et al. 1999). But when Wieser et al. (1995) performed the converse of this experiment by expression of a constitutively active TGF $\beta$ type I receptor (T $\beta R I(T 204 D))$, this resulted in increased PTHrP production, marked osteolytic bone metastasis, and decreased survival. Finally, overexpression of PTHrP in MDA-MB-231 cells bearing the inactive $\mathrm{T} \beta$ RII $\Delta$ cyt receptor increased PTHrP production and accelerated the development of osteolytic metastasis (Yin et al. 1999). These experiments establish that both TGF $\beta$ receptor activation and PTHrP are crucial for the development and progression of osteolytic bone metastasis. The TGF $\beta$ signal is transduced by the $\mathrm{p} 38$ mitogen-activated protein kinase (MAPK) and the Smad pathways in the MDA-MB-231 breast cancer cell line. The combination of Smad dominant-negative blockade and p38 MAPK inhibition results in complete inhibition of TGF $\beta$-stimulated PTHrP production (Kakonen et al. 2002b).

Other osteolysis-stimulating factors. Osteoclastic resorption of bone releases high concentrations of ionised calcium and phosphate from the dissolution of the bone mineral. The $\mathrm{CaR}$ is a $\mathrm{G}$ protein-coupled, seven-transmembrane domain receptor, which responds to small variations in the concentration of extracellular calcium (Yamaguchi et al. 2000). The $\mathrm{CaR}$ is expressed by breast cancer cells and regulates tumour secretion of PTHrP (Buchs et al. 2000, Sanders et al. 2000), an effect which is enhanced by TGF $\beta$. Thus, the high concentrations of ionized calcium in bone may contribute to the vicious cycle by increasing PTHrP production and osteolysis. Small molecule agonists and antagonists of the receptor have been developed and are in clinical trials (Nemeth 2002). Such agents might be effective against breast cancer bone metastases. The IGFs are also released into the local bone environment during osteolysis and likely also have a role in the proliferation of bone metastases (Sachdev \& Yee 2001, Yoneda et al. 2001). Hauschka 


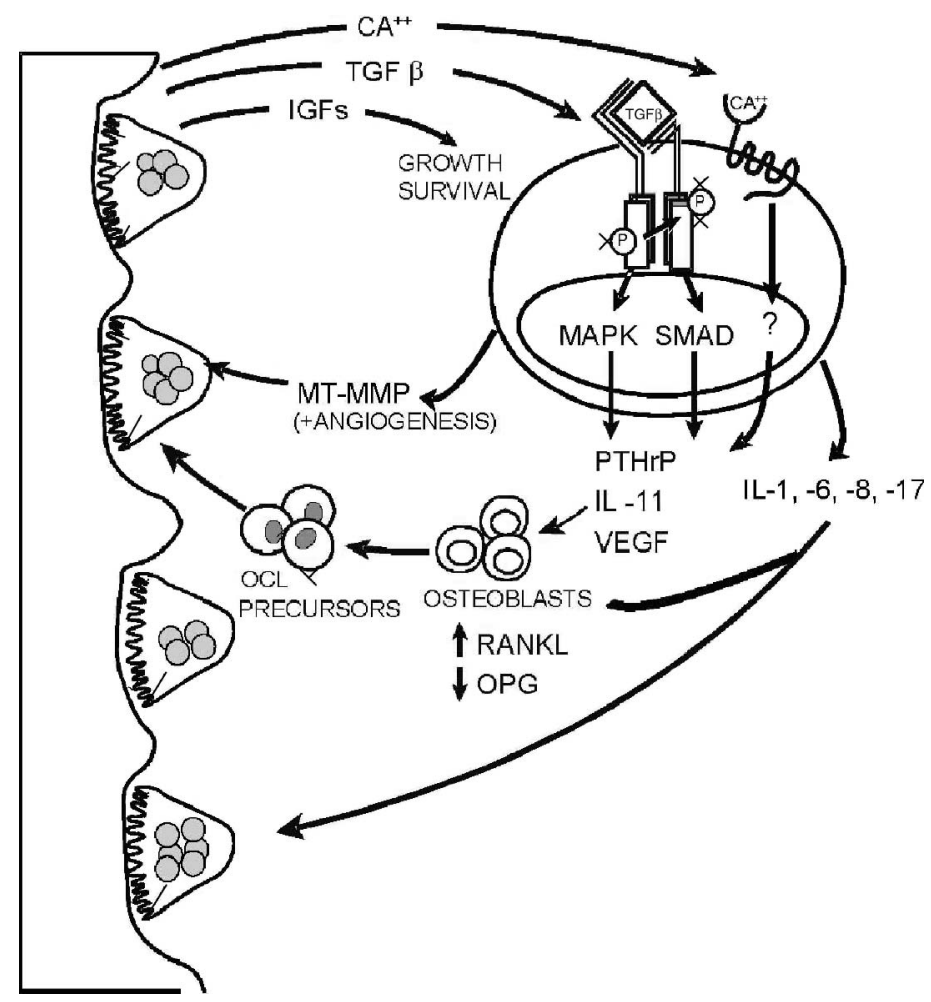

Figure 2 Bone resorption in breast cancer osteolytic metastases. PTHrP secreted by tumour cells increases RANKL and decreases OPG activity, resulting in increased osteoclastogenesis. This escalation in bone resorption leads to higher levels of TGF $\beta$, which activates tumour cells to produce even more PTHrP, thus the 'vicious cycle' of osteolytic bone metastases begins. Other factors immobilised in bone that are released during osteoclast-mediated resorption include members of the IGF family. IL-1, $-6,-8$ and -17 and MMPs are secreted by tumour cells and appear to participate and stimulate osteoclastogenesis. OCL, osteoclast; MT-MMP, membrane type-matrix metalloproteinase.

et al. (1986) found that IGF-II, then IGF-I, were the most abundant factors in bone matrix, followed by TGF $\beta$, after which were lower concentrations of BMPs, fibroblast growth factors-1 and -2 and PDGF. However, only TGF $\beta$ has been shown to play a direct role in stimulating tumour cells.

Interactions between tumour and bone - the vicious cycle. Preclinical animal models have established that bone metastasis involves a vicious cycle between tumour cells and the skeleton (Fig. 2). The cycle is fueled by four contributors: the tumour cells, bone-forming osteoblasts, bone-destroying osteoclasts and organic bone matrix. Osteoclast formation and activity are regulated by the osteoblast, adding further complexity. The mineralised matrix of bone is a vast storehouse of growth factors, such as insulin-like and transforming growth factors (Hauschka et al. 1986). These are synthesised by osteoblasts and released by osteoclasts. The factors reach high local concentrations in the bone microenvironment and can act on tumour cells to encourage metastatic growth. It was realized 25 years ago that the products released from resorbing bone were attractants for tumour cells (Orr et al. 1979). In turn, breast cancer cells secrete many factors that act on bone cells. It is likely that at sites of osteoblastic metastases tumour cells continue to secrete osteolytic factors, such as PTHrP, which stimulate bone resorption. Therapies targeting the vicious cycle would be expected to decrease metastases by lowering the concentrations of growth factors in bone.

\section{Osteoblastic metastasis}

Osteoblastic metastases are commonly associated with prostate cancer and to a much lesser degree with breast cancer. Osteoblastic bone lesions have been described in other malignancies such as an osteosclerotic variant of myeloma (Anonymous 1972), colon cancer (Paling \& Pope 1988), astrocytoma (Kingston et al. 1986), glioblastoma multiforme (Gamis et al. 1990), thymoma (MCLennan 1991), carcinoid (Giordano et al. 1994), nasopharyngeal carcinoma (Liaw 
et al. 1994), leptomeningial gliomatosis (Pingi et al. 1995), Zollinger-Ellison syndrome (Pederson et al. 1976) and cervical carcinoma (George \& Lai 1995). Just as with breast cancer-mediated osteolysis, the seed and soil hypothesis applies to prostate cancer in that the bone microenvironment readily supports the growth of prostate cancer cells (Koutsilieris 1995). The key difference, however, is that prostate tumour cells secrete factors that stimulate bone formation rather than destruction.

The seed and soil analogy of Paget can be applied to osteoblastic metastases, which share a similar pathophysiology with osteolytic metastases. The tumour cells, or seeds, secrete factors that stimulate osteoblast activity and bone formation. The bone microenvironment is enriched with osteoblast-derived growth factors, which enhance the local growth of tumour cells. Histomorphometric studies of prostate cancer samples indicate that osteoblastic metastases are due to tumour-produced factors that stimulate bone formation (Charhon et al. 1983, Koutsilieris 1995).

Data such as these suggest that prostate cancer cells produce factors that stimulate disregulated bone formation. The following tumour products have been proposed to be important in the genesis of the osteoblastic response to tumour cells in bone.

Endothelin-1 (ET-1). ET-1 is a 21 amino acid peptide found to be a potent vasoconstrictor. It is expressed by many tissues and binds to two $G$ protein-coupled receptors. It is also a potent osteoblast-stimulatory factor through its activation of the ET A receptor (ETAR) (Guise et al. 2003). Many receptor-selective ET receptor antagonists have been developed by the pharmaceutical industry for the treatment of cardiovascular conditions (Remuzzi et al. 2002). ET-1 plays an important role in cancer and on osteoblastic bone metastases in particular (Nelson et al. 2003a).

We established an animal model of osteoblastic metastases using three standard human breast cancer cell lines, ZR-75.1, T47D and MCF7. All three lines are oestrogen receptor positive and express ET-1 but not PTHrP. The ZR75.1 cell line was studied in the greatest detail. It stimulates new bone formation in organ culture and causes osteoblastic metastases in vivo. Bone formation and metastases were effectively blocked with a selective antagonist of the ETAR (Yin et al. 2003). This orally active antagonist, atrasentan, is in clinical trials in men with advanced metastatic prostate cancer (Rosenbaum \& Carducci 2003). The vicious cycle model (Fig. 3) predicts that osteoblasts, osteoclasts and tumour cells co-operate to cause the pathology of bone metastases. The ET receptor

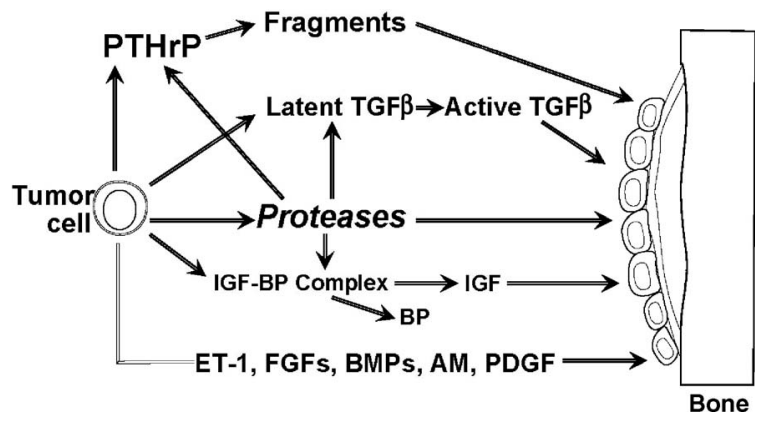

Figure 3 Bone formation in prostate cancer osteoblastic metastases. Secreted products of prostate cancer cells that stimulate osteoblast proliferation and new bone formation have been identified and these include ET-1, fibroblast growth factors (FGFs), BMPs, adrenomedullin and PDGF. The tumour production of proteases, most notably PSA, cleaves PTHrP, TGF $\beta$ and IGF from its binding protein, resulting in the generation of fragments with osteoblast stimulating activity.

antagonist blocks the activation of osteoblasts by tumour-produced ET-1. It also decreases osteoclastic bone resorption, as indicated by decreases in markers of resorption seen in patient trials (Nelson et al. 2003b). Conversely, bisphosphonates effectively reduce skeletal-related events (SREs) in prostate cancer (Saad et al. 2002). The observations support a role for the vicious cycle in cancer patients. These results suggest that bisphosphonates should be effective therapy against all types of bone metastases and that ET receptor antagonists may be useful in the treatment of osteoblastic metastases due to breast cancer.

Other factors. Other factors responsible for osteoblastic metastases remain to be critically tested. Such factors need to meet two initial criteria: (1) ability to stimulate osteoblastic new bone formation and (2) expression by cancer cells. The bone morphogenetic proteins are obvious candidates, but a causal role in bone metastases has not been demonstrated. CTGF, identified in the experiments of Kang et al. (2003), is another factor that stimulates osteoblasts (Safadi et al. 2003). Adrenomedullin is a 52 amino acid vasoactive peptide with potent bone-stimulatory actions (Cornish \& Naot 2002), which is produced by many cancers (Zudaire et al. 2003). We have unpublished data from lung and prostate cancer cell lines which suggest that adrenomedullin increases bone metastases in vivo. It is also an autocrine growth factor for breast cancer cells (Miller et al. 1996) and is transcriptionally regulated in endometrial cells by tamoxifen (Oehler et al. 2000). Its role in breast cancer bone metastases has not yet been investigated. 
Mixed osteolytic-osteoblastic metastases are characteristic of both breast and prostate cancers. The effects of combined expression of osteolytic and osteoblastic factors on bone have not been studied, so the net response of bone at the metastatic site is unpredictable. Osteolytic factors such as PTHrP and IL-11 act on osteoblasts to increase expression of RANKL. We tested the effects of introducing the osteoblastic factor ET-1 into the PTHrP-secreting MDA-MB-231 breast cancer cell line. Instead of converting the bone response from osteolytic to osteoblastic, the bone-destructive effects were enhanced by ET-1 (J J Yin, J M Chirgwin \& T A Guise, unpublished observations). Some of this effect may be caused by autocrine responses of the tumour cells to ET-1. Osteoblastic factors can stimulate osteoblast proliferation, increasing the population of early osteoblasts (Coffman 2003). The enlarged pool of early osteoblasts responds to osteolytic factors by increased expression of RANKL (Deyama et al. 2000, Geoffroy et al. 2002). Recently Yi et al. (2002) overexpressed PDGF B-chain in MDA-MB-231 cells and observed osteosclerotic rather than osteolytic metastases.

A puzzling question has been the role of PTHrP in osteoblastic metastases, especially those due to prostate cancer, which nearly always express PTHrP. A partial explanation was provided by the observation that prostate-specific antigen (PSA) is a serine proteinase which cleaves PTHrP after residue 23 (Cramer et al. 1996, Iwamura et al. 1996). The resulting fragment fails to activate the classical PTH/PTHrP receptor. It was later observed that the inactive fragment PTHrP(1-16) increased cAMP in cardiomyocytes by activating the ETAR. Binding was attributed to a four amino acid near-identity between the two peptides (Schluter et al. 2001). We have extended these observations to bone. $\mathrm{PTHrP}(1-23)$ is a potent stimulator of calvarial new bone formation at concentrations as low as $1 \mathrm{nM}$. PSA is commonly expressed in breast cancer (Black \& Diamandis 2000). The results suggest that PSA proteolysis, rather than inactivating PTHrP, converts it from an osteolytic factor to a potent osteoblastic one. This process may occur in breast cancer bone metastases. Proteolytic cleavage of IGF from its binding protein (Fielder et al. 1994) and the processing of latent TGF $\beta$ to the active form (Killian et al. 1993) by PSA may also contribute to osteoblast stimulation.

Tumour cells may also secrete factors that oppose the development and progression of bone metastases. IL-18, which decreases osteoclast formation, is one such factor made by cancer cells (Nakata et al. 1999, Iwasaki et al. 2002). This unexplored territory may reveal exciting new approaches for future antimetastatic therapies. Similarly, the role of the immune system in bone metastases is understudied (Roodman 2003), as is angiogenesis (van der Pluijm et al. 2000).

\section{Treatment of metastatic bone disease}

\section{Hormone therapies}

The treatment of metastatic bone disease often requires a multidisciplinary approach, involving a medical oncologist, radiation oncologist and a surgeon. Systemic chemotherapeutic agents are often used and can have beneficial effects in bone metastases. Endocrine treatments for prostate and breast cancer are considered first-line therapies for tumours that are hormone responsive. Androgen blockade in men with advanced prostate cancer can reduce tumour burden and bone pain. The use of luteinizing hormonereleasing hormone agonists and anti-androgens are effective and are often preferred over older treatments such as orchiectomy. However, most prostate cancers will overcome androgen blockade after several years and transform to androgen independence. Selective oestrogen receptor modulators (SERMs) such as tamoxifen, and possibly raloxifene and toremifene, have benefit in the primary and secondary prevention of breast cancer (Anonymous 1988, Fisher et al. 1998, Pyrhonen et al. 1999, Cauley et al. 2001). Two aromatase inhibitors, anastrozole and letrozole, are approved in the USA for treatment of postmenopausal patients with advanced disease (Buzdar et al. 2001). These medications will likely replace SERMs as firstline treatment for breast cancer. Comparative clinical trials with tamoxifen demonstrate the superiority of aromatase inhibitors in length of disease progression and survival (Bonneterre et al. 2000, Mouridsen et al. 2003, Nabholtz et al. 2003). However as compared with tamoxifen, aromatase inhibitors resulted in increased bone resorption (Heshmati et al. 2002) and fracture risk (Howell et al. 2005).

\section{External beam radiation}

Prophylactic external beam radiation to prevent fracture in weight-bearing bones in conjunction with surgical fixation can prevent significant morbidity. The use of external beam radiation in the treatment of focal bone pain is also quite effective (Tong et al. 1982). Patients with extensive bone metastases can undergo hemibody irradiation but at the expense of increased toxicity. Controversy exists on the optimum dose and schedule of therapy. Multiple studies have examined whether higher doses of radiation with shorter 
fractions are more beneficial than lower doses and more fractions; no study has, however, been entirely convincing. Recent meta-analysis (Wu et al. 2003) demonstrated no significant differences for pain scores using single or multi-fraction therapy as palliative treatment. A survey of American radiation oncologists revealed different practice methods among physicians in the USA and in Canada. Most radiation oncologists in the USA employ $30 \mathrm{~Gy}$ in ten fractions while in Canada, 20 Gy in five fractions is often used (Chow et al. 2000).

Spinal cord or cauda equina compression by a spinal metastasis is a medical emergency requiring prompt evaluation and treatment in order to preserve and protect neurological function. In addition to focal back pain, radicular symptoms and signs include lower extremity muscle weakness, loss of bowel/bladder function and ataxia. Plain films have limited value in this situation and evaluation with MRI or myelography is required to identify the presence of a spinal lesion and cord compromise. High-dose corticosteroids in conjunction with external beam radiation or surgical decompression can result in significant return of neurological function if treatment is initiated within 24-36h of symptoms (Maranzano \& Latini 1995). Until recently, laminectomy was the preferred management in patients with cord compression but studies have shown no differences in outcome with radiation therapy (Young et al. 1980). Therefore, radiation therapy with corticosteroids is considered first-line therapy.

\section{Radioisotopes}

Radioisotopes with an affinity for bone have been studied in patients with metastatic breast and prostate cancer with painful bony metastases. Phosphorus-32 had been used in the past but has been surpassed by newer agents. Strontium- $89\left({ }^{89} \mathrm{Sr}\right)$ is a high-energy $\beta$ particle-emitting radioisotope that has been shown to be effective in decreasing pain. In one study, patients with prostate cancer and metastatic bone disease were randomized to receive either ${ }^{89} \mathrm{Sr}$ or external beam radiation (focal or hemibody depending on the extensiveness of the metastases) (Quilty et al. 1994). Both treatments were highly effective, although there was no significant difference in pain relief scores. However, patients randomized to the ${ }^{89} \mathrm{Sr}$ treatment had fewer subsequent painful bony sites and this result was likely due to the systemic nature of this therapy. The radioisotope samarium-135 $\left({ }^{135} \mathrm{Sm}\right)$ is also effective in alleviating pain in bone metastases (Serafini 2000) and has several advantages over ${ }^{89} \mathrm{Sr} .{ }^{135} \mathrm{Sm}$ has a shorter half-life (2 days) and therefore the delivery of larger doses over a shorter amount of time is possible. This radioisotope emits a lower energy particle than other radioisotopes, which translates into reduced bone marrow toxicity.

\section{Surgery}

Prophylactic surgical correction of bone metastases is indicated for impending fractures in weight-bearing bones. Osteolytic lesions that encompass a large area of bone have a high likelihood of fracture with breast and kidney metastases having the highest risk (Higenbotham \& Marcove 1965). Fracture from osteoblastic metastases from malignancies such as prostate is unusual. Although pathological fracture at any location can result in significant pain, fracture of the femur, humerus, pelvis and vertebrae results in the most disability and fixation at these locations is indicated. Management of impending fracture includes plate osteosynthesis, nailing and insertion of prosthetic implants (Harrington 1997). Adjuvant radiotherapy after fixation can reduce further metastatic destruction.

\section{Bisphosphonates}

Bisphosphonates are unique in the treatment of metastatic bone disease as this is a bone-targeted therapy. The use of bisphosphonates in the treatment of osteolytic bone disease due to breast cancer also appears to have benefit. Two large trials have been published evaluating pamidronate in patients with stage IV breast cancer; the data were later combined in order to evaluate long-term benefit (Lipton et al. 2000). Patients were randomised to pamidronate $(90 \mathrm{mg})$ or placebo every 3-4 weeks, and the primary outcome was skeletal events per year and time to first SRE. Despite a significant number of participants not completing the study, the number of events per year in the treatment group was 2.4 compared with 3.7 in the control group. Also, the median time to the first SRE was longer in the treatment group.

A phase II trial evaluating the effective dose of zoledronic acid compared with pamidronate in patients with osteolytic lesions due to multiple myeloma or metastatic breast cancer was published in 2001 (Berenson et al. 2001). Zoledronic acid (0.4, 2.0 or $4.0 \mathrm{mg}$ ) was compared with $90 \mathrm{mg}$ pamidronate administered every 4 weeks up to 10 months. The primary end-point was the need for radiation therapy to bone during the treatment period, whereby secondary endpoints included SRE, bone mineral density and bone pain. The $2.0 \mathrm{mg}$ and $4.0 \mathrm{mg}$ zoledronic acid-treated groups had an equivalent rate of radiation therapy 
requirement as the pamidronate arm, but the $0.4 \mathrm{mg}$ zoledronic acid-treated group underwent radiotherapy at a higher rate. A follow-up phase III trial with a similar patient population compared zoledronic acid $(4 \mathrm{mg}$ and $8 \mathrm{mg}$ ) with pamidronate $(90 \mathrm{mg}$ ) infusion given every 3-4 weeks for 24 months (Rosen et al. 2003). SREs were the primary end-point over 25 months. Due to a decline in renal function in patients randomised to $8 \mathrm{mg}$ zoledronic acid, this dose was reduced to $4 \mathrm{mg}$. Zoledronic acid reduced the risk of skeletal complications by $16 \%$ compared with pamidronate. The oral bisphosphonate clodronate may also have benefit in preventing SREs (Kanis et al. 1996, Powles et al. 2002), but has not been approved for use in the USA.

The use of bisphosphonates in the treatment of prostate cancer has been controversial as bone metastases are usually osteoblastic and bisphosphonates exert their effects via osteoclasts. However, recent studies have shown a benefit. Patients with hormonerefractory metastatic prostate cancer were assigned to receive zoledronic acid $(4 \mathrm{mg}$ and $8 \mathrm{mg}$ ) followed later with $4 \mathrm{mg}$ or placebo every 3 weeks for 18 months. Subjects who received zoledronic acid had less SREs and pain compared with the control group, but there was no significant difference in disease progression or performance status (Saad et al. 2002). Androgen deprivation therapy for prostate cancer can adversely affect bone mineral density and the indication for the use of bisphosphonates in this situation is clearer. One study in men with early stage hormone-responsive disease treated with androgen ablation therapy showed that $4 \mathrm{mg}$ zoledronic acid administered every 3 months for 1 year had an increase in lumbar spine bone mineral density compared with a decrease in the control group (Smith et al. 2003).

Zoledronic acid has been effective in the treatment of bone metastases from other solid tumours, including lung, kidney and colorectal. In a recent phase III trial, 733 patients with metastatic bone disease were randomised to zoledronic acid $(4 \mathrm{mg})$ or placebo. Infusions were administered every 3 weeks for a treatment duration of 21 months. The treatment group had a statistically significant reduction in time to first SRE but there was no effect in mortality (Rosen et al. 2003). Of note, in most bisphosphonate trials patients received supplementation with calcium and vitamin $\mathrm{D}$. This often-neglected detail is important, since the use of bisphosphonates in the presence of vitamin D deficiency may impair bone mineralization.

A major morbidity for patients with skeletal metastases is intractable bone pain, which is reduced by bisphosphonate treatment (Heidenreich et al. 2001).
The mechanisms of pain caused by bone metastases are specific and complex. Factors produced by tumour cells, as well as molecules released by bone remodelling, stimulate pain receptors in bone (Mantyh et al. 2002). Interruption of the vicious cycle with bisphosphonates can thus reduce the concentration of painstimulating molecules in the microenvironment surrounding metastatic tumour cells.

Substantial controversy surrounds clinical data on the effects of bisphosphonates on breast cancer tumour burden at extra-skeletal sites (Boissier et al. 2000, Diel et al. 2000). As discussed above, bisphosphonates have direct anti-tumour actions in vitro, but it remains unclear whether the compounds reach sufficiently high local concentrations in non-bone sites to produce such actions in patients. The bisphosphonates have the potential to enhance anti-tumour activities of known cytotoxic agents, but further and larger clinical trials are required to address the importance of the preclinical data. In vitro, bisphosphonates have direct effects on tumour cells to reduce tumour growth (Lee et al. 2002) and invasiveness (Derenne et al. 1999, Virtanen et al. 2002), as well as to induce apoptosis (van der Pluijm et al. 1996, Senaratne et al. 2000). Bisphosphonates may also impact other components of the metastatic cascade by reducing adhesion of tumour cells to bone (Boissier et al. 1997, Oefelein et al. 2002) and by inhibiting angiogenesis (Fournier et al. 2002). In the latter study, zoledronic acid reduced testosterone-induced revascularisation of the prostate in rats, the effect of which was due to transient accumulation of the bisphosphonate in the prostate (Fournier et al. 2002).

Questions still remain to be answered about the use of bisphosphonates for metastatic bone disease: which is the best bisphosphonate, what is the ideal dose, for how long can it be administered, how should it be administered, should it be given to patients early in the course of the disease and, most important, do these drugs have a beneficial effect on survival? Also, what are the effects of bisphosphonates on the tumour cells themselves? Finally, what is the role of bisphosphonate therapy in the treatment of osteoporosis due to cancer treatment, independent of the presence of bone metastases?

\section{ETAR antagonists}

Recent data show an important role for tumoursecreted ET-1 in osteoblastic metastases. ET-1 is a potent stimulator of osteoblast proliferation and new bone formation. Tumours secreting ET-1 cause osteoblastic metastasis in an animal model and the 
metastases can be blocked with an ETAR antagonist (Yin et al. 2003). This antagonist, atrasentan, has completed a phase II clinical trial in men with hormone-refractory prostate cancer (Carducci et al. 2003). The agent delayed time to progression and decreased markers of tumour burden. Of particular interest, atrasentan decreased markers of bone remodelling, which were elevated in patients with prostate cancer (Nelson et al. 2003b). This result supports the importance of the vicious cycle model, in which targeting one step serves to suppress all parts of the cycle. Two other ETAR-selective antagonists, YM 598 and AZD 4054, are in clinical trial for treatment of prostate cancer (Nelson et al. 2003a). Other selective and non-selective ET receptor antagonists have been developed and are being investigated for treatment of pulmonary hypertension, congestive heart failure and chronic renal failure (Remuzzi et al. 2002).

\section{Novel therapies}

Although the current therapy for bone metastases results in a significant reduction in morbidity, such therapy does not promote regression of established disease. Thus, new therapies are under development. Novel therapies for osteolytic bone disease based on inhibition of the RANK/RANKL system have been proposed and several are in clinical trial. A phase I trial studying recombinant osteoprotegerin (AMGN-0007) in patients with multiple myeloma or bone metastases from breast cancer was recently published (Body et al. 2003b). However, concerns remain about adverse effects and theoretical concerns of decreasing cancer cell apoptosis. OPG is also a receptor for the TNF-like ligand TRAIL and this molecule has been shown to be involved in apoptotic signalling in cancer cells. A humanized RANKL antibody, AMG-162, has been developed and has shown promise in phase I clinical trials. The biological half-life after a single subcutaneous injection was at least 2 months and adverse effects were minimal. In breast cancer patients with metastases to bone, AMG-162 reduced urinary markers of bone resorption (Bekker et al. 2004). Integrins also appear to be important in the development of bone metastases (Bakewell et al. 2003). Mice injected with melanoma cells that result in osteolytic metastases had increased survival when treated with a monoclonal antibody to the integrin $\alpha_{\mathrm{v}} \beta_{3}$ (Sparks et al. 2003). Integrin inhibitors are currently in phase II human trials (Tucker 2003). Vitamin D analogues have shown promise in preclinical models of breast cancer metastasis to bone, the mechanism of which is unclear but may involve inhibition of tumour growth or of PTHrP production. Humanised PTHrP antibodies are in clinical trials for women with breast cancer metastatic to bone, but data regarding efficacy are not yet available. The tyrosine kinase c-Src promotes tumourigenesis and increases metastatic potential of tumour cells (Parsons \& Parsons 2004). Mice inactivated for c-Src have osteopetrosis, demonstrating an additional role of this kinase in osteoclast function (Marzia et al. 2000). Inhibitors of this tyrosine kinase are being investigated for treatment of osteolytic bone metastases (Boyce et al. 2003).

Non-steroidal inflammatory agents (NSAIDs) and selective cyclo-oxygenase-2 (COX-2) inhibitors may reduce the risk of colon cancer (Thun et al. 1991, Rahme et al. 2003). This benefit may be related to increased expression of COX-2 in malignant versus normal colon epithelia (Eberhart et al. 1994). NSAIDs may also have a role in protecting against prostate cancer (Mahmud et al. 2004). Animal models of prostate cancer and sarcoma have shown a decrease in bone tumour burden with COX-2 inhibitors (Sabino et al. 2002, Gupta et al. 2004). The recent withdrawal of the COX-2 inhibitor rofecoxib, due to increased cardiovascular risk, may limit the future use of these agents.

Results based upon the exponential growth of the mechanisms underlying tumour metastases to bone indicate that many new therapies will be developed in the next 5 years. Possible targets include CTGF, CXCR4, MMPs, TGF $\beta$, IL-11, IL-8 and signal transduction inhibitors of the MAPK pathway. These new therapies may be useful in combination with the existing bisphosphonate treatments. Future preclinical and clinical trials will determine the importance of these newly identified targets in achieving regression of established bone metastases and in preventing the development of new disease.

\section{Conclusion}

Recent discoveries in the pathogenesis and treatment of bone metastases have been possible due to a more complete understanding of the molecular interactions between cancer cells and bone. Normal bone remodelling is complex and it has become clear that cancer cells with the propensity to flourish within the bone microenvironment have developed abilities not only to proliferate in bone but to coax osteoblasts and osteoclasts to produce factors within the bone microenvironment that further stimulate cancer cell growth. Thus, the development of treatments to break or at least reduce the 'vicious cycle' is key. Bisphosphonates have been shown to reduce SREs due to bone 
metastases, but these drugs neither prevent metastases nor reduce cancer burden within bone. The majority of cancer therapies are aimed at systemic eradication of cancer cells but tailored therapies focusing on the treatment of specific cancers that metastasise to particular organs and tissues are the future of cancer therapy.

\section{Acknowledgements}

The authors were supported by grants from the NIH, CA40035 and CA69158, the Department of Defense, The Prostate Cancer Foundation and The University of Virginia (Cancer Center, Mellon Institute, Gerald D Aurbach Endowment). The authors declare that there is no conflict of interest that would prejudice the impartiality of this scientific work.

\section{References}

Abou-Samra AB, Juppner H, Force T, Freeman MW, Kong XF, Schipani E, Urena P, Richards J, Bonventre JV, Potts JT Jr et al. 1992 Expression cloning of a common receptor for parathyroid hormone and parathyroid hormone-related peptide from rat osteoblastlike cells: a single receptor stimulates intracellular accumulation of both cAMP and inositol trisphosphates and increases intracellular free calcium. PNAS 89 2732-2736.

Adams JS, Sharma OP, Gacad MA \& Singer FR 1983 Metabolism of 25-hydroxyvitamin D3 by cultured pulmonary alveolar macrophages in sarcoidosis. Journal of Clinical Investigation 72 1856-1860.

Anderson DM, Maraskovsky E, Billingsley WL, Dougall WC, Tometsko ME, Roux ER, Teepe MC, DuBose RF, Cosman D \& Galibert L 1997 A homologue of the TNF receptor and its ligand enhance T-cell growth and dendritic-cell function. Nature 390 175-179.

Anonymous 1972 Case records of the Massachusetts General Hospital. Weekly clinicopathological exercises. Case 29-1972. New England Journal of Medicine 287 $138-143$.

Anonymous 1988 Effects of adjuvant tamoxifen and of cytotoxic therapy on mortality in early breast cancer. An overview of 61 randomized trials among 28896 women. Early Breast Cancer Trialists' Collaborative Group (Comment). New England Journal of Medicine 319 1681-1692.

Arguello F, Baggs RB \& Frantz CN 1988 A murine model of experimental metastasis to bone and bone marrow. Cancer Research 48 6876-6881.

Asa SL, Henderson J, Goltzman D \& Drucker DJ 1990 Parathyroid hormone-like peptide in normal and neoplastic human endocrine tissues. Journal of Clinical Endocrinology and Metabolism 71 1112-1118.
Bachelder RE, Wendt MA \& Mercurio AM 2002 Vascular endothelial growth factor promotes breast carcinoma invasion in an autocrine manner by regulating the chemokine receptor CXCR4. Cancer Research 62 7203-7206.

Bachmeier BE, Nerlich AG, Lichtinghagen R \& Sommerhoff CP 2001 Matrix metalloproteinases (MMPs) in breast cancer cell lines of different tumorigenicity. Anticancer Research 21 3821-3828.

Bakewell SJ, Nestor P, Prasad S, Tomasson MH, Dowland N, Mehrotra M, Scarborough R, Kanter J, Abe K, Phillips D \& Weilbaecher K 2003 Platelet and osteoclast beta-3 integrins are critical for bone metastasis. PNAS, 100 14205-14210.

Bao L, Loda M, Janmey PA, Stewart R, Anand-Apte B \& Zetter BR 1996 Thymosin beta 15: a novel regulator of tumor cell motility upregulated in metastatic prostate cancer (Comment). Nature Medicine 2 1322-1328.

Barbour GL, Coburn JW, Slatopolsky E, Norman AW \& Horst RL 1981 Hypercalcemia in an anephric patient with sarcoidosis: evidence for extrarenal generation of 1,25-dihydroxyvitamin D. New England Journal of Medicine 305 440-443.

Barhoum M, Hutchins L \& Fonseca VA 1999 Intractable hypercalcemia due to a metastatic carcinoid secreting parathyroid hormone-related peptide and interleukin-6: response to octreotide. American Journal of the Medical Sciences 318 203-205.

Bekker PJ, Holloway DL, Rasmussen AS, Murphy R, Martin SW, Leese PT, Holmes GB, Dunstan CR \& DePaoli AM 2004 A single-dose placebo-controlled study of AMG 162, a fully human monoclonal antibody to RANKL, in postmenopausal women. Journal of Bone \& Mineral Research 19 1059-1066.

Bell NH 1985 Vitamin D-endocrine system. Journal of Clinical Investigation 76 1-6.

Bendre MS, Gaddy-Kurten D, Mon-Foote T, Akel NS, Skinner RA, Nicholas RW \& Suva LJ 2002 Expression of interleukin 8 and not parathyroid hormone-related protein by human breast cancer cells correlates with bone metastasis in vivo. Cancer Research 62 5571-5579.

Berenson JR, Rosen LS, Howell A, Porter L, Coleman RE, Morley W, Dreicer R, Kuross SA, Lipton A \& Seaman JJ 2001 Zoledronic acid reduces skeletal-related events in patients with osteolytic metastases. Cancer 91 1191-1200.

Berruti A, Dogliotti L, Tucci M, Tarabuzzi R, Guercio S, Torta M, Tampellini M, Dovio A, Poggio M, Scarpa RM et al. 2002 Metabolic effects of single-dose pamidronate administration in prostate cancer patients with bone metastases. International Journal of Biological Markers 17 244-252.

Bertolini DR, Nedwin GE, Bringman TS, Smith DD \& Mundy GR 1986 Stimulation of bone resorption and inhibition of bone formation in vitro by human tumour necrosis factors. Nature 319 516-518.

Binstock ML \& Mundy GR 1980 Effect of calcitonin and glutocorticoids in combination on the hypercalcemia of malignancy. Annals of Internal Medicine 93 269-272. 
Black K, Garrett IR \& Mundy GR 1991 Chinese hamster ovarian cells transfected with the murine interleukin-6 gene cause hypercalcemia as well as cachexia, leukocytosis and thrombocytosis in tumor-bearing nude mice. Endocrinology 128 2657-2659.

Black MH \& Diamandis EP 2000 The diagnostic and prognostic utility of prostate-specific antigen for diseases of the breast. Breast Cancer Research and Treatment 59 $1-14$.

Body JJ, Coleman RE, Lipton A, Murphy R, Holloway DL, Bekker PJ \& DePaoli AM $2003 a$ Rapid, profound, and prolonged suppression of bone turnover with a single SC dose of AMG 162 in women with breast cancer metastatic to bone. Proceedings of the IVth International Conference on Cancer-Induced Bone Diseases, San Antonio, TX, USA.

Body JJ, Greipp P, Coleman RE, Facon T, Geurs F, Fermand JP, Harousseau JL, Lipton A, Mariette X, Williams CD et al. 2003b A Phase I study of AMGN0007, a recombinant osteoprotegerin construct, in patients with multiple myeloma or breast carcinoma related bone metastases. Cancer 97 887-892.

Boissier S, Magnetto S, Frappart L, Cuzin B, Ebetino FH, Delmas PD \& Clezardin P 1997 Bisphosphonates inhibit prostate and breast carcinoma cell adhesion to unmineralized and mineralized bone extracellular matrices. Cancer Research 57 3890-3894.

Boissier S, Ferreras M, Peyruchaud O, Magnetto S, Ebetino FH, Colombel M, Delmas P, Delaisse JM \& Clezardin P 2000 Bisphosphonates inhibit breast and prostate carcinoma cell invasion, an early event in the formation of bone metastases. Cancer Research 60 2949-2954.

Bonneterre J, Thurlimann B, Robertson JF, Krzakowski M, Mauriac L, Koralewski P, Vergote I, Webster A, Steinberg M \& von Euler M 2000 Anastrozole versus tamoxifen as first-line therapy for advanced breast cancer in 668 postmenopausal women: results of the Tamoxifen or Arimidex Randomized Group Efficacy and Tolerability study (Comment). Journal of Clinical Oncology 18 3748-3757.

Botella A, Rekik M, Delvaux M, Davicco MJ, Barlet JP, Frexinos J \& Bueno L 1994 Parathyroid hormone (PTH) and PTH-related peptide induce relaxation of smooth muscle cells from guinea pig ileum: interaction with vasoactive intestinal peptide receptors. Endocrinology 135 2160-2167.

Boyce BF, Aufdemorte TB, Garrett IR, Yates AJ \& Mundy GR 1989 Effects of interleukin-1 on bone turnover in normal mice. Endocrinology 125 1142-1150.

Boyce BF, Xing L, Shakespeare W, Wang Y, Dalgarno D, Iuliucci J \& Sawyer T 2003 Regulation of bone remodeling and emerging breakthrough drugs for osteoporosis and osteolytic bone metastases. Kidney International 85 (Suppl) S2-S5.

Boyde A, Maconnachie E, Reid SA, Delling G \& Mundy GR 1986 Scanning electron microscopy in bone pathology: review of methods. In Scanning Electron Microscopy, edn IV, Scanning Electron Microscopy, Inc., ELK Grove Village, Illinois, USA, pp 1537-1554.

Brenza HL \& DeLuca HF 2000 Regulation of 25hydroxyvitamin D3 1alpha-hydroxylase gene expression by parathyroid hormone and 1,25-dihydroxyvitamin D3. Archives of Biochemistry and Biophysics 381 143-152.

Breslau NA, McGuire JL, Zerwekh JE, Frenkel EP \& Pak CY 1984 Hypercalcemia associated with increased serum calcitriol levels in three patients with lymphoma. Annals of Internal Medicine 100 1-6.

Brown EM, Gamba G, Riccardi D, Lombardi M, Butters R, Kifor O, Sun A, Hediger MA, Lytton J \& Hebert SC 1993 Cloning and characterization of an extracellular $\mathrm{Ca}(2+)$-sensing receptor from bovine parathyroid. Nature 366 575-580.

Buchs N, Manen D, Bonjour JP \& Rizzoli R 2000 Calcium stimulates parathyroid hormone-related protein production in Leydig tumor cells through a putative cation-sensing mechanism. European Journal of Endocrinology 142 500-505.

Bundred NJ, Ratcliffe WA, Walker RA, Coley S, Morrison JM \& Ratcliffe JG 1991 Parathyroid hormone related protein and hypercalcaemia in breast cancer. British Medical Journal 303 1506-1509.

Bundred NJ, Walker RA, Ratcliffe WA, Warwick J, Morrison JM \& Ratcliffe JG 1992 Parathyroid hormone related protein and skeletal morbidity in breast cancer. European Journal of Cancer 28 690-692.

Burtis WJ, Brady TG, Orloff JJ, Ersbak JB, Warrell RP Jr, Olson BR, Wu TL, Mitnick ME, Broadus AE \& Stewart AF 1990 Immunochemical characterization of circulating parathyroid hormone-related protein in patients with humoral hypercalcemia of cancer. New England Journal of Medicine 322 1106-1112.

Buzdar A, Douma J, Davidson N, Elledge R, Morgan M, Smith R, Porter L, Nabholtz J, Xiang X \& Brady C 2001 Phase III, multicenter, double-blind, randomized study of letrozole, an aromatase inhibitor, for advanced breast cancer versus megestrol acetate. Journal of Clinical Oncology 19 3357-3366.

Carducci MA, Padley RJ, Breul J, Vogelzang NJ, Zonnenberg BA, Daliani DD, Schulman CC, Nabulsi AA, Humerickhouse RA, Weinberg MA et al. 2003 Effect of endothelin-A receptor blockade with atrasentan on tumor progression in men with hormone-refractory prostate cancer: a randomized, phase II, placebocontrolled trial. Journal of Clinical Oncology 21 679-689.

Cauley JA, Norton L, Lippman ME, Eckert S, Krueger KA, Purdie DW, Farrerons J, Karasik A, Mellstrom D, Ng KW et al. 2001 Continued breast cancer risk reduction in postmenopausal women treated with raloxifene: 4-year results from the MORE trial. Multiple outcomes of raloxifene evaluation. Breast Cancer Research and Treatment $\mathbf{6 5}$ 125-134.

Chambers TJ \& Magnus CJ 1982 Calcitonin alters behaviour of isolated osteoclasts. Journal of Pathology $13627-39$. 
Charhon SA, Chapuy MC, Delvin EE, Valentin-Opran A, Edouard CM \& Meunier PJ 1983 Histomorphometric analysis of sclerotic bone metastases from prostatic carcinoma special reference to osteomalacia. Cancer $\mathbf{5 1}$ 918-924.

Chen HL, Demiralp B, Schneider A, Koh AJ, Silve C, Wang CY \& McCauley LK $2002 a$ Parathyroid hormone and parathyroid hormone-related protein exert both pro- and anti-apoptotic effects in mesenchymal cells. Journal of Biological Chemistry 277 19374-19381.

Chen WT, Shih TT, Chen RC, Lo HY, Chou CT, Lee JM \& Tu HY 2002b Blood perfusion of vertebral lesions evaluated with gadolinium-enhanced dynamic MRI: in comparison with compression fracture and metastasis. Journal of Magnetic Resonance Imaging 15 308-314.

Chirgwin JM \& Guise TA 2000 Molecular mechanisms of tumor-bone interactions in osteolytic metastases. Critical Reviews in Eukaryotic Gene Expression 10 159-178.

Chow E, Danjoux C, Wong R, Szumacher E, Franssen E, Fung K, Finkelstein J, Andersson L \& Connolly R 2000 Palliation of bone metastases: a survey of patterns of practice among Canadian radiation oncologists. Radiotherapy and Oncology 56 305-314.

Coffman JA 2003 Runx transcription factors and the developmental balance between cell proliferation and differentiation. Cell Biology International Reports 27 315-324.

Coleman RE \& Rubens RD 1987 The clinical course of bone metastases from breast cancer. British Journal of Cancer 55 61-66.

Cooper CR, Chay CH, Gendernalik JD, Lee HL, Bhatia J, Taichman RS, McCauley LK, Keller ET \& Pienta KJ 2003 Stromal factors involved in prostate carcinoma metastasis to bone. Cancer 97 739-747.

Cornish J \& Naot D 2002 Amylin and adrenomedullin: novel regulators of bone growth. Current Pharmaceutical Design 8 2009-2021.

Costa L, Demers LM, Gouveia-Oliveira A, Schaller J, Costa EB, de Moura MC \& Lipton A 2002 Prospective evaluation of the peptide-bound collagen type I crosslinks $\mathrm{N}$-telopeptide and C-telopeptide in predicting bone metastases status. Journal of Clinical Oncology 20 850-856.

Cramer SD, Chen Z \& Peehl DM 1996 Prostate specific antigen cleaves parathyroid hormone-related protein in the PTH-like domain: inactivation of PTHrP-stimulated cAMP accumulation in mouse osteoblasts. Journal of Urology 156 526-531.

Dallas SL, Rosser JL, Mundy GR \& Bonewald LF 2002 Proteolysis of latent transforming growth factor-beta (TGF-beta)-binding protein-1 by osteoclasts. A cellular mechanism for release of TGF-beta from bone matrix. Journal of Biological Chemistry 277 21352-21360.

Danks JA, Ebeling PR, Hayman J, Chou ST, Moseley JM, Dunlop J, Kemp BE \& Martin TJ 1989 Parathyroid hormone-related protein: immunohistochemical localization in cancers and in normal skin. Journal of Bone and Mineral Research 4 273-278.

Derenne S, Amiot M, Barille S, Collette M, Robillard N, Berthaud P, Harousseau JL \& Bataille R 1999 Zoledronate is a potent inhibitor of myeloma cell growth and secretion of IL-6 and MMP-1 by the tumoral environment. Journal of Bone and Mineral Research 14 2048-2056.

Deyama Y, Takeyama S, Koshikawa M, Shirai Y, Yoshimura Y, Nishikata M, Suzuki K \& Matsumoto A 2000 Osteoblast maturation suppressed osteoclastogenesis in coculture with bone marrow cells. Biochemical and Biophysical Research Communications 274 249-254.

Deyo RA \& Diehl AK 1988 Cancer as a cause of back pain: frequency, clinical presentation, and diagnostic strategies. Journal of General Internal Medicine 3 230-238.

Diel IJ, Solomayer EF \& Bastert G 2000 Bisphosphonates and the prevention of metastasis: first evidences from preclinical and clinical studies. Cancer 88 3080-3088.

Eberhart CE, Coffey RJ, Radhika A, Giardiello FM, Ferrenbach S \& DuBois RN 1994 Up-regulation of cyclooxygenase 2 gene expression in human colorectal adenomas and adenocarcinomas. Gastroenterology 107 1183-1188.

Egeblad M \& Werb Z 2002 New functions for the matrix metalloproteinases in cancer progression. Nature Reviews Cancer 2 161-174.

Eilon G \& Mundy GR 1978 Direct resorption of bone by human breast cancer cells in vitro. Nature 276 726-728.

Favus MJ 2003 Laboratory values of importance for calcium metabolism and metabolic bone disease. In Primer on the Metabolic Bone Diseases and Disorders of Mineral Metabolism, Ed: Favus MJ, pp 545-547. Washington DC: American Society for Bone and Mineral Research.

Felding-Habermann B, O'Toole TE, Smith JW, Fransvea E, Ruggeri ZM, Ginsberg MH, Hughes PE, Pampori N, Shattil SJ, Saven A et al. 2001 Integrin activation controls metastasis in human breast cancer. PNAS 98 1853-1858.

Festuccia C, Giunciuglio D, Guerra F, Villanova I, Angelucci A, Manduca P, Teti A, Albini A \& Bologna M 1999 Osteoblasts modulate secretion of urokinase-type plasminogen activator (uPA) and matrix metalloproteinase-9 (MMP-9) in human prostate cancer cells promoting migration and matrigel invasion. Oncology Research 11 17-31.

Fetchick DA, Bertolini DR, Sarin PS, Weintraub ST, Mundy GR \& Dunn JF 1986 Production of 1,25dihydroxyvitamin D3 by human T cell lymphotrophic virus-I-transformed lymphocytes. Journal of Clinical Investigation 78 592-596.

Fielder PJ, Rosenfeld RG, Graves HC, Grandbois K, Maack CA, Sawamura S, Ogawa Y, Sommer A \& Cohen P 1994 Biochemical analysis of prostate specific antigen-proteolyzed insulin-like growth factor binding protein-3. Growth Regulation 4 164-172. 
Fierabracci P, Pinchera A, Miccoli P, Conte PF, Vignali E, Zaccagnini M, Marcocci C \& Giani C 2001 Increased prevalence of primary hyperparathyroidism in treated breast cancer. Journal of Endocrinological Investigation 24 315-320.

Firkin F, Seymour JF, Watson AM, Grill V \& Martin TJ 1996 Parathyroid hormone-related protein in hypercalcaemia associated with haematological malignancy. British Journal of Haematology 94 486-492.

Fisher B, Costantino JP, Wickerham DL, Redmond CK, Kavanah M, Cronin WM, Vogel V, Robidoux A, Dimitrov N, Atkins J et al. 1998 Tamoxifen for prevention of breast cancer: report of the National Surgical Adjuvant Breast and Bowel Project P-1 Study. Journal of the National Cancer Institute 90 1371-1388.

Fleisch H 1991 Bisphosphonates. Pharmacology and use in the treatment of tumour-induced hypercalcaemic and metastatic bone disease. Drugs 42 919-944.

Fournier P, Boissier S, Filleur S, Guglielmi J, Cabon F, Colombel M \& Clezardin P 2002 Bisphosphonates inhibit angiogenesis in vitro and testosterone-stimulated vascular regrowth in the ventral prostate in castrated rats. Cancer Research 62 6538-6544.

Friedman J, Au WY \& Raisz LG 1968 Responses of fetal rat bone to thyrocalcitonin in tissue culture. Endocrinology 82 149-156.

Fukumitsu N, Uchiyama M, Mori Y, Yanada S, Hatano T, Igarashi H, Kishimoto K, Nakada J, Yoshihiro A \& Harada J 2002 Correlation of urine type I collagencross-linked $\mathrm{N}$ telopeptide levels with bone scintigraphic results in prostate cancer patients. Metabolism (Clinical and Experimental) 51 814-818.

Funk JL, Shigenaga JK, Moser AH, Krul EJ, Strewler GJ, Feingold KR \& Grunfeld C 1994 Cytokine regulation of parathyroid hormone-related protein messenger ribonucleic acid levels in mouse spleen: paradoxical effects of interferon-gamma and interleukin-4. Endocrinology 135 351-358.

Funk JL, Lausier J, Moser AH, Shigenaga JK, Huling S, Nissenson RA, Strewler GJ, Grunfeld C \& Feingold KR 1995 Endotoxin induces parathyroid hormone-related protein gene expression in splenic stromal and smooth muscle cells, not in splenic lymphocytes. Endocrinology 136 3412-3421.

Galasko CSB 1981 The Anatomy and Pathways of Skeletal Metastases. Eds I Weiss \& AH Gilbert. Boston: GK Hall.

Galasko CS \& Bennett A 1976 Relationship of bone destruction in skeletal metastases to osteoclast activation and prostaglandins. Nature 263 508-510.

Gamis AS, Egelhoff J, Roloson G, Young J, Woods GM, Newman R \& Freeman AI 1990 Diffuse bony metastases at presentation in a child with glioblastoma multiforme. A case report. Cancer 66 180-184.

Garnero P 2001 Markers of bone turnover in prostate cancer. Cancer Treatment Reviews 27 187-192.

Geminder H, Sagi-Assif O, Goldberg L, Meshel T, Rechavi G, Witz IP \& Ben-Baruch A 2001 A possible role for
CXCR4 and its ligand, the CXC chemokine stromal cell-derived factor-1, in the development of bone marrow metastases in neuroblastoma. Journal of Immunology 167 4747-4757.

Geoffroy V, Kneissel M, Fournier B, Boyde A \& Matthias P 2002 High bone resorption in adult aging transgenic mice overexpressing cbfa1/runx2 in cells of the osteoblastic lineage. Molecular and Cellular Biology 22 6222-6233.

George J \& Lai FM 1995 Metastatic cervical carcinoma presenting as psoas abscess and osteoblastic and lytic bony metastases. Singapore Medical Journal 36 224-227.

Gillespie MT \& Horwood NJ 1998 Interleukin-18: perspectives on the newest interleukin. Cytokine and Growth Factor Reviews 9 109-116.

Giordano N, Nardi P, Vigni P, Palumbo F, Battisti E \& Gennari C 1994 Osteoblastic metastases from carcinoid tumor. Clinical and Experimental Rheumatology 12 228-229.

Giuliani N, Pedrazzoni M, Passeri G \& Girasole G $1998 a$ Bisphosphonates inhibit IL-6 production by human osteoblast-like cells. Scandinavian Journal of Rheumatology 27 38-41.

Giuliani N, Pedrazzoni M, Negri G, Passeri G, Impicciatore M \& Girasole G $1998 b$ Bisphosphonates stimulate formation of osteoblast precursors and mineralized nodules in murine and human bone marrow cultures in vitro and promote early osteoblastogenesis in young and aged mice in vivo. Bone 22 455-461.

Gkonos PJ, London R \& Hendler ED 1984 Hypercalcemia and elevated 1,25-dihydroxyvitamin $\mathrm{D}$ levels in a patient with end-stage renal disease and active tuberculosis. New England Journal of Medicine 311 1683-1685.

Green JR \& Clezardin P 2002 Mechanisms of bisphosphonate effects on osteoclasts, tumor cell growth, and metastasis. American Journal of Clinical Oncology 25 S3-S9.

Grill V \& Martin TJ 2000 Hypercalcemia of malignancy. Reviews in Endocrine and Metabolic Disorders 1 253-263.

Grill V, Ho P, Body JJ, Johanson N, Lee SC, Kukreja SC, Moseley JM \& Martin TJ 1991 Parathyroid hormonerelated protein: elevated levels in both humoral hypercalcemia of malignancy and hypercalcemia complicating metastatic breast cancer. Journal of Clinical Endocrinology and Metabolism 73 1309-1315.

Gucalp R, Ritch P, Wiernik PH, Sarma PR, Keller A, Richman SP, Tauer K, Neidhart J, Mallette LE, Siegel R et al. 1992 Comparative study of pamidronate disodium and etidronate disodium in the treatment of cancerrelated hypercalcemia. Journal of Clinical Oncology 10 134-142.

Guise TA 1997 Parathyroid hormone-related protein and bone metastases. Cancer 80 1572-1580.

Guise TA \& Mundy GR 1996 Physiological and pathological roles of parathyroid hormone-related peptide. Current Opinion in Nephrology and Hypertension 5 307-315. 
Guise TA, Garrett IR, Bonewald LF \& Mundy GR 1993 Interleukin-1 receptor antagonist inhibits the hypercalcemia mediated by interleukin-1. Journal of Bone and Mineral Research 8 583-587.

Guise TA, Taylor SD, Yoneda T, Sasaki A, Wright KR, Boyce BF, Chirgwin JM \& Mundy GR 1994 PTHrP expression by breast cancer cells enhance osteolytic bone metastases in vivo. Journal of Bone and Mineral Research 9 S128.

Guise TA, Yin JJ, Taylor SD, Kumagai Y, Dallas M, Boyce BF, Yoneda T \& Mundy GR 1996 Evidence for a causal role of parathyroid hormone-related protein in the pathogenesis of human breast cancer-mediated osteolysis. Journal of Clinical Investigation 98 1544-1549.

Guise TA, Yin JJ \& Mohammad KS 2003 Role of endothelin-1 in osteoblastic bone metastases. Cancer 97 779-784

Gupta S, Adhami VM, Subbarayan M, MacLennan GT, Lewin JS, Hafeli UO, Fu P \& Mukhtar H 2004 Suppression of prostate carcinogenesis by dietary supplementation of celecoxib in transgenic adenocarcinoma of the mouse prostate model. Cancer Research 64 3334-3343.

Harrington KD 1997 Orthopedic surgical management of skeletal complications of malignancy. Cancer $\mathbf{8 0}$ 1614-1627.

Hauschka PV, Mavrakos AE, Iafrati MD, Doleman SE \& Klagsbrun M 1986 Growth factors in bone matrix. Isolation of multiple types by affinity chromatography on heparin-Sepharose. Journal of Biological Chemistry 261 12665-12674.

Heersche JN, Marcus R \& Aurbach GD 1974 Calcitonin and the formation of $3^{\prime}, 5^{\prime}$-AMP in bone and kidney. Endocrinology 94 241-247.

Heidenreich A, Hofmann R \& Engelmann UH 2001 The use of bisphosphonate for the palliative treatment of painful bone metastasis due to hormone refractory prostate cancer. Journal of Urology 165 136-140.

Helbig G, Christopherson KW 2nd, Bhat-Nakshatri P, Kumar S, Kishimoto H, Miller KD, Broxmeyer HE \& Nakshatri H 2003 NF-kappaB promotes breast cancer cell migration and metastasis by inducing the expression of the chemokine receptor CXCR4. Journal of Biological Chemistry 278 21631-21638.

Heshmati HM, Khosla S, Robins SP, O'Fallon WM, Melton LJ 3rd \& Riggs BL 2002 Role of low levels of endogenous estrogen in regulation of bone resorption in late postmenopausal women. Journal of Bone and Mineral Research 17 172-178.

Higenbotham NL \& Marcove RC 1965 The management of pathological fractures. Journal of Trauma 5 792-798.

Holtrop ME, Cox KA, Clark MB, Holick MF \& Anast CS 1981 1,25-dihydroxycholecalciferol stimulates osteoclasts in rat bones in the absence of parathyroid hormone. Endocrinology 108 2293-2301.

Horiuchi N, Caulfield MP, Fisher JE, Goldman ME, McKee RL, Reagan JE, Levy JJ, Nutt RF, Rodan SB,
Schofield TL et al. 1987 Similarity of synthetic peptide from human tumor to parathyroid hormone in vivo and in vitro. Science 238 1566-1568.

Horwitz MJ, Tedesco MB, Sereika SM, Hollis BW, Garcia-Ocana A \& Stewart AF 2003 Direct comparison of sustained infusion of human parathyroid hormonerelated protein-(1-36) [hPTHrP-(1-36)] versus hPTH(1-34) on serum calcium, plasma 1,25-dihydroxyvitamin D concentrations, and fractional calcium excretion in healthy human volunteers. Journal of Clinical Endocrinology and Metabolism 88 1603-1609.

Hosking DJ, Cowley A \& Bucknall CA 1981 Rehydration in the treatment of severe hypercalcaemia. Quarterly Journal of Medicine 50 473-481.

Howell A, Cuzick J, Baum M, Buzdar A, Dowsett M, Forbes JF, Hoctin-Boes G, Houghton J, Locker GY, Tobias JS et al. 2005 Results of the ATAC (Arimidex, Tamoxifen, Alone or in Combination) trial after completion of 5 years' adjuvant treatment for breast cancer. Lancet 365 60-62.

Hulter HN, Halloran BP, Toto RD \& Peterson JC 1985 Long-term control of plasma calcitriol concentration in dogs and humans. Dominant role of plasma calcium concentration in experimental hyperparathyroidism. Journal of Clinical Investigation 76 695-702.

Ibbotson KJ, Twardzik DR, D’Souza SM, Hargreaves WR, Todaro GJ \& Mundy GR 1985 Stimulation of bone resorption in vitro by synthetic transforming growth factor-alpha. Science 228 1007-1009.

Iguchi H, Tanaka S, Ozawa Y, Kashiwakuma T, Kimura T, Hiraga T, Ozawa H \& Kono A 1996 An experimental model of bone metastasis by human lung cancer cells: the role of parathyroid hormone-related protein in bone metastasis. Cancer Research 56 4040-4043.

Iguchi H, Miyagi C, Tomita K, Kawauchi S, Nozuka Y, Tsuneyoshi M \& Wakasugi H 1998 Hypercalcemia caused by ectopic production of parathyroid hormone in a patient with papillary adenocarcinoma of the thyroid gland. Journal of Clinical Endocrinology and Metabolism $832653-2657$.

Ikeda K, Ohno H, Hane M, Yokoi H, Okada M, Honma T, Yamada A, Tatsumi Y, Tanaka T, Saitoh T et al. 1994 Development of a sensitive two-site immunoradiometric assay for parathyroid hormone-related peptide: evidence for elevated levels in plasma from patients with adult T-cell leukemia/lymphoma and B-cell lymphoma. Journal of Clinical Endocrinology and Metabolism 79 1322-1327.

Iwamura M, Hellman J, Cockett AT, Lilja H \& Gershagen S 1996 Alteration of the hormonal bioactivity of parathyroid hormone-related protein (PTHrP) as a result of limited proteolysis by prostate-specific antigen. Urology 48 317-325.

Iwasaki T, Yamashita K, Tsujimura T, Kashiwamura S, Tsutsui H, Kaisho T, Sugihara A, Yamada N, Mukai M, Yoneda T et al. 2002 Interleukin-18 inhibits osteolytic bone metastasis by human lung cancer cells possibly 
through suppression of osteoclastic bone-resorption in nude mice. Journal of Immunotherapy 25 S52-S60.

Jarvik JG \& Deyo RA 2002 Diagnostic evaluation of low back pain with emphasis on imaging. Annals of Internal Medicine 137 586-597.

Jeffery CJ, Bahnson BJ, Chien W, Ringe D \& Petsko GA 2000 Crystal structure of rabbit phosphoglucose isomerase, a glycolytic enzyme that moonlights as neuroleukin, autocrine motility factor, and differentiation mediator. Biochemistry 39 955-964.

Jemal A, Tiwari RC, Murray T, Ghafoor A, Samuels A, Ward E, Feuer EJ, Thun MJ \& American Cancer Society 2004 Cancer statistics 2004. Ca: a Cancer Journal for Clinicians 54 8-29.

Johnson RA, Boyce BF, Mundy GR \& Roodman GD 1989 Tumors producing human tumor necrosis factor induced hypercalcemia and osteoclastic bone resorption in nude mice. Endocrinology 124 1424-1427.

Juppner H, Abou-Samra AB, Freeman M, Kong XF, Schipani E, Richards J, Kolakowski LF Jr, Hock J, Potts JT Jr, Kronenberg HM et al. 1991 A G proteinlinked receptor for parathyroid hormone and parathyroid hormone-related peptide. Science 254 1024-1026.

Kakonen SM, Kang Y, Carreon MR, Niewolna M, Kakonen RS, Chirgwin JM, Massague J \& Guise TA $2002 a$ Breast cancer cell lines selected from bone metastases have greater metastatic capacity and express increased vascular endothelial growth factor (VEGF), interleukin-11 (IL-11), and parathyroid hormone-related protein (PTHrP). Journal of Bone and Mineral Metabolism 17 S409.

Kakonen SM, Selander KS, Chirgwin JM, Yin JJ, Burns S, Rankin WA, Grubbs BG, Dallas M, Cui Yb \& Guise TA $2002 b$ Transforming growth factor-beta stimulates parathyroid hormone-related protein and osteolytic metastases via Smad and mitogen-activated protein kinase signaling pathways. Journal of Biological Chemistry 277 24571-24578.

Kang Y, Siegel PM, Shu W, Drobnjak M, Kakonen SM, Cordon-Cardo C, Guise TA \& Massague AJ 2003 A multigenic program mediating breast cancer metastasis to bone. Cancer Cell 3 537-549.

Kanis JA, Urwin GH, Gray RE, Beneton MN, McCloskey EV, Hamdy NA \& Murray SA 1987 Effects of intravenous etidronate disodium on skeletal and calcium metabolism. American Journal of Medicine 82 55-70.

Kanis JA, Powles T, Paterson AH, McCloskey EV \& Ashley S 1996 Clodronate decreases the frequency of skeletal metastases in women with breast cancer. Bone 19 663-667.

Karadag A, Fedarko N \& Fisher L 2003 Bone sialoprotein promotes invasion through basement membrane by forming a complex with both MMP-2 and integrin avb3. Journal of Bone and Mineral Research 18 S111.

Kawashima H, Kraut JA \& Kurokawa K 1982 Metabolic acidosis suppresses 25-hydroxyvitamin D3-1alphahydroxylase in the rat kidney. Distinct site and mechanism of action. Journal of Clinical Investigation 70 135-140.

Killian CS, Corral DA, Kawinski E \& Constantine RI 1993 Mitogenic response of osteoblast cells to prostate-specific antigen suggests an activation of latent TGF-beta and a proteolytic modulation of cell adhesion receptors. Biochemical and Biophysical Research Communications 192 940-947.

Kingston JE, Plowman PN, Smith BF \& Garvan NJ 1986 Differentiated astrocytoma with osteoblastic skeletal metastases in a child. Childs Nervous System 2 219-221.

Kiriyama T, Gillespie MT, Glatz JA, Fukumoto S, Moseley JM \& Martin TJ 1993 Transforming growth factor beta stimulation of parathyroid hormone-related protein (PTHrP): a paracrine regulator? (Erratum appears in Molecular and Cellular Endocrinology 199394 145). Molecular and Cellular Endocrinology 92 55-62.

Klein BY, Ben-Bassat H, Breuer E, Solomon V \& Golomb G 1998 Structurally different bisphosphonates exert opposing effects on alkaline phosphatase and mineralization in marrow osteoprogenitors. Journal of Cellular Biochemistry 68 186-194.

Klein DC \& Raisz LG 1970 Prostaglandins: stimulation of bone resorption in tissue culture. Endocrinology $\mathbf{8 6}$ 1436-1440.

Kohno N, Kitazawa S, Fukase M, Sakoda Y, Kanbara Y, Furuya Y, Ohashi O, Ishikawa Y \& Saitoh Y 1994 The expression of parathyroid hormone-related protein in human breast cancer with skeletal metastases. Surgery Today 24 215-220.

Kostenuik PJ, Singh G, Suyama KL \& Orr FW 1992 A quantitative model for spontaneous bone metastasis: evidence for a mitogenic effect of bone on Walker 256 cancer cells. Clinical and Experimental Metastasis 10 403-410.

Koutsilieris M 1995 Skeletal metastases in advanced prostate cancer: cell biology and therapy. Critical Reviews in Oncology/Hematology 18 51-64.

Kovacs CS, Lanske B, Hunzelman JL, Guo J, Karaplis AC \& Kronenberg HM 1996 Parathyroid hormone-related peptide (PTHrP) regulates fetal-placental calcium transport through a receptor distinct from the $\mathrm{PTH} /$ PTHrP receptor. PNAS 93 15233-15238.

Kremer R, Shustik C, Tabak T, Papavasiliou V \& Goltzman D 1996 Parathyroid-hormone-related peptide in hematologic malignancies. American Journal of Medicine 100 406-411.

Lacey DL, Timms E, Tan HL, Kelley MJ, Dunstan CR, Burgess T, Elliott R, Colombero A, Elliott G, Scully S et al. 1998 Osteoprotegerin ligand is a cytokine that regulates osteoclast differentiation and activation. Cell 93 165-176.

Lacey DL, Tan HL, Lu J, Kaufman S, Van G, Qiu W, Rattan A, Scully S, Fletcher F, Juan T et al. 2000 Osteoprotegerin ligand modulates murine osteoclast survival in vitro and in vivo. American Journal of Pathology 157 435-448. 
LeBoff MS \& Mikulec KH 2003 Hypercalcemia: clinical manifestations, pathogenesis, diagnosis, and management. In Primer on the Metabolic Bone Diseases and Disorders of Mineral Metabolism, pp 225-229. edn 5. Ed. MJ Favus. Washington DC: American Society for Bone and Mineral Research.

Lee YP, Schwarz EM, Davies M, Jo M, Gates J, Zhang X, Wu J \& Lieberman JR 2002 Use of zoledronate to treat osteoblastic versus osteolytic lesions in a severecombined-immunodeficient mouse model. Cancer Research 62 5564-5570.

Lemieux P, Harvey J, Guise T, Dallas M, Oesterreich S, Yin J, Selander K \& Fuqua S 1999 Low cell motility induced by hsp27 overexpression decreases osteolytic bone metastases of human breast cancer cells in vivo. Journal of Bone and Mineral Research 14 1570-1575.

Li H, Seitz PK, Selvanayagam P, Rajaraman S \& Cooper CW 1996 Effect of endogenously produced parathyroid hormone-related peptide on growth of a human hepatoma cell line (Hep G2). Endocrinology 137 2367-2374.

Li X, Choi SJ, Grubbs BG, Cui Y, Roodman GD, Guise TA \& Chirgwin JM 2000 Autocrine motility factor (AMF) is a species-specific stimulator of periosteal new bone formation in vivo. American Society for Bone and Mineral Research Meeting, Toronto, Canada, Abstract no. SU139.

Liapis H, Crouch EC, Grosso LE, Kitazawa S \& Wick MR 1993 Expression of parathyroidlike protein in normal, proliferative, and neoplastic human breast tissues. American Journal of Pathology 143 1169-1178.

Liaw CC, Ho YS, Koon-Kwan NG, Chen TL \& Tzann WC 1994 Nasopharyngeal carcinoma with brain metastasis: a case report. Journal of Neuro-Oncology 22 227-230.

Lipton A, Theriault RL, Hortobagyi GN, Simeone J, Knight RD, Mellars K, Reitsma DJ, Heffernan M \& Seaman JJ 2000 Pamidronate prevents skeletal complications and is effective palliative treatment in women with breast carcinoma and osteolytic bone metastases: long term follow-up of two randomized, placebo-controlled trials. Cancer 88 1082-1090.

Luparello C, Ginty AF, Gallagher JA, Pucci-Minafra I \& Minafra S 1993 Transforming growth factor-beta 1, beta 2 , and beta 3 , urokinase and parathyroid hormonerelated peptide expression in $8701-\mathrm{BC}$ breast cancer cells and clones. Differentiation 55 73-80.

Luparello C, Burtis WJ, Raue F, Birch MA \& Gallagher JA 1995 Parathyroid hormone-related peptide and 8701-BC breast cancer cell growth and invasion in vitro: evidence for growth-inhibiting and invasion-promoting effects. Molecular and Cellular Endocrinology $111225-232$.

Lynch CC \& Matrisian LM 2003 Osteoprotegerin ligand is cleaved to a soluble functional form by MMP-3 and MMP-7. Proceedings of the IVth International Conference on Cancer-Induced Bone Diseases, Paget Foundation, San Antonio, Texas, Abstract 13.

McLennan MK 1991 Case report 657: malignant epithelial thymoma with osteoplastic metastases. Skeletal Radiology 20 141-144.
Mahmud S, Franco E \& Aprikian A 2004 Prostate cancer and use of nonsteroidal anti-inflammatory drugs: systematic review and meta-analysis. British Journal of Cancer 90 93-99.

Mahon MJ, Donowitz M, Yun CC \& Segre GV $2002 \mathrm{Na}(+) /$ $\mathrm{H}(+)$ exchanger regulatory factor 2 directs parathyroid hormone 1 receptor signalling. Nature 417 858-861.

Major P, Lortholary A, Hon J, Abdi E, Mills G, Menssen HD, Yunus F, Bell R, Body J, Quebe-Fehling E et al. 2001 Zoledronic acid is superior to pamidronate in the treatment of hypercalcemia of malignancy: a pooled analysis of two randomized, controlled clinical trials. Journal of Clinical Oncology 19 558-567.

Mantyh PW, Clohisy DR, Koltzenburg M \& Hunt SP 2002 Molecular mechanisms of cancer pain. Nature Reviews Cancer 2 201-209.

Maranzano E \& Latini P 1995 Effectiveness of radiation therapy without surgery in metastatic spinal cord compression: final results from a prospective trial. International Journal of Radiation Oncology-BiologyPhysics 32 959-967.

Martin TJ, Romas E \& Gillespie MT 1998 Interleukins in the control of osteoclast differentiation. Critical Reviews in Eukaryotic Gene Expression 8 107-123.

Marzia M, Sims NA, Voit S, Migliaccio S, Taranta A, Bernardini S, Faraggiana T, Yoneda T, Mundy GR, Boyce BF et al. 2000 Decreased c-Src expression enhances osteoblast differentiation and bone formation. Journal of Cell Biology 151 311-320.

Mason RS, Frankel T, Chan YL, Lissner D \& Posen S 1984 Vitamin D conversion by sarcoid lymph node homogenate. Annals of Internal Medicine 100 59-61.

Massague J 1998 TGF-beta signal transduction. Annual Review of Biochemistry 67 753-791.

Massague J, Hata A \& Liu F 1997 TGF-beta signalling through the Smad pathway. Trends in Cell Biology 7 187-192.

de la Mata J, Uy HL, Guise TA, Story B, Boyce BF, Mundy GR \& Roodman GD 1995 Interleukin-6 enhances hypercalcemia and bone resorption mediated by parathyroid hormone-related protein in vivo. Journal of Clinical Investigation 95 2846-2852.

Matsuura N, Puzon-McLaughlin W, Irie A, Morikawa Y, Kakudo K \& Takada Y 1996 Induction of experimental bone metastasis in mice by transfection of integrin alpha 4 beta 1 into tumor cells. American Journal of Pathology 148 55-61.

Mbalaviele G, Dunstan CR, Sasaki A, Williams PJ, Mundy GR \& Yoneda T 1996 E-cadherin expression in human breast cancer cells suppresses the development of osteolytic bone metastases in an experimental metastasis model. Cancer Research 56 4063-4070.

Mercier RJ, Thompson JM, Harman GS \& Messerschmidt GL 1988 Recurrent hypercalcemia and elevated 1,25dihydroxyvitamin D levels in Hodgkin's disease. American Journal of Medicine 84 165-168.

Merryman JI, DeWille JW, Werkmeister JR, Capen CC \& Rosol TJ 1994 Effects of transforming growth factor-beta 
on parathyroid hormone-related protein production and ribonucleic acid expression by a squamous carcinoma cell line in vitro. Endocrinology 134 2424-2430.

Michigami T, Shimizu N, Williams PJ, Niewolna M, Dallas SL, Mundy GR \& Yoneda T 2000 Cell-cell contact between marrow stromal cells and myeloma cells via VCAM-1 and alpha(4)beta(1)-integrin enhances production of osteoclaststimulating activity. Blood 96 1953-1960.

Miller MJ, Martinez A, Unsworth EJ, Thiele CJ, Moody TW, Elsasser T \& Cuttitta F 1996

Adrenomedullin expression in human tumor cell lines. Its potential role as an autocrine growth factor. Journal of Biological Chemistry $27123345-23351$.

Minina E, Wenzel HM, Kreschel C, Karp S, Gaffield W, McMahon AP \& Vortkamp A 2001 BMP and Ihh/PTHrP signaling interact to coordinate chondrocyte proliferation and differentiation. Development 128 4523-4534.

Moallem E, Kilav R, Silver J \& Naveh-Many T 1998 RNA-protein binding and post-transcriptional regulation of parathyroid hormone gene expression by calcium and phosphate. Journal of Biological Chemistry 273 5253-5259.

Mohan S \& Baylink DJ 1991 Bone growth factors. Clinical Orthopaedics and Related Research 263 30-48.

Moonga BS, Alam AS, Bevis PJ, Avaldi F, Soncini R, Huang CL \& Zaidi M 1992 Regulation of cytosolic free calcium in isolated rat osteoclasts by calcitonin. Journal of Endocrinology 132 241-249.

Moseley JM, Kubota M, Diefenbach-Jagger H, Wettenhall RE, Kemp BE, Suva LJ, Rodda CP, Ebeling PR, Hudson PJ, Zajac JD et al. 1987 Parathyroid hormonerelated protein purified from a human lung cancer cell line. PNAS 84 5048-5052.

Mouridsen H, Gershanovich M, Sun Y, Perez-Carrion R, Boni C, Monnier A, Apffelstaedt J, Smith R, Sleeboom HP, Jaenicke F et al. 2003 Phase III study of letrozole versus tamoxifen as first-line therapy of advanced breast cancer in postmenopausal women: analysis of survival and update of efficacy from the International Letrozole Breast Cancer Group (Comment). Journal of Clinical Oncology 21 2101-2109.

Moz Y, Rilav R, Silver J \& Naveh-Many T 2002 A leader sequence in the PTH mRNA 5 -untranslated region (UTR) regulates PTH translation. Journal of Bone and Mineral Research 17 S285.

Muller A, Homey B, Soto H, Ge N, Catron D, Buchanan ME, McClanahan T, Murphy E, Yuan W, Wagner SN et al. 2001 Involvement of chemokine receptors in breast cancer metastasis. Nature 410 50-56.

Mundy GR 1995 Hypercalcemia. In Bone Remodeling and its Disorders, pp 88-103. Ed. GR Mundy. London: Martin Dunitz.

Mundy GR \& Martin TJ 1982 The hypercalcemia of malignancy: pathogenesis and management. Metabolism (Clinical and Experimental) 31 1247-1277.

Mundy GR \& Guise TA 1999 Hormonal control of calcium homeostasis. Clinical Chemistry 45 1347-1352.
Mundy GR, Rick ME, Turcotte R \& Kowalski MA 1978 Pathogenesis of hypercalcemia in lymphosarcoma cell leukemia. Role of an osteoclast activating factor-like substance and a mechanism of action for glucocorticoid therapy. American Journal of Medicine 65 600-606.

Mundy GR, Wilkinson R \& Heath DA 1983 Comparative study of available medical therapy for hypercalcemia of malignancy. American Journal of Medicine 74 421-432.

Myoui A, Nishimura R, Williams PJ, Hiraga T, Tamura D, Michigami T, Mundy GR \& Yoneda T 2003 C-SRC tyrosine kinase activity is associated with tumor colonization in bone and lung in an animal model of human breast cancer metastasis. Cancer Research 63 5028-5033.

Nabholtz JM, Bonneterre J, Buzdar A, Robertson JF \& Thurlimann B 2003 Anastrozole (Arimidex) versus tamoxifen as first-line therapy for advanced breast cancer in postmenopausal women: survival analysis and updated safety results. (Comment). European Journal of Cancer 39 1684-1689.

Nakai M, Mundy GR, Williams PJ, Boyce B \& Yoneda T 1992 A synthetic antagonist to laminin inhibits the formation of osteolytic metastases by human melanoma cells in nude mice. Cancer Research 52 5395-5399.

Nakata A, Tsujimura T, Sugihara A, Okamura H, Iwasaki T, Shinkai K, Iwata N, Kakishita E, Akedo H \& Terada N 1999 Inhibition by interleukin 18 of osteolytic bone metastasis by human breast cancer cells. Anticancer Research 19 4131-4138.

Nakayama K, Fukumoto S, Takeda S, Takeuchi Y, Ishikawa T, Miura M, Hata K, Hane M, Tamura Y, Tanaka Y et al. 1996 Differences in bone and vitamin D metabolism between primary hyperparathyroidism and malignancy-associated hypercalcemia. Journal of Clinical Endocrinology and Metabolism 81 607-611.

Nakopoulou L, Tsirmpa I, Alexandrou P, Louvrou A, Ampela C, Markaki S \& Davaris PS 2003 MMP-2 protein in invasive breast cancer and the impact of MMP-2/ TIMP-2 phenotype on overall survival. Breast Cancer Research and Treatment 77 145-155.

Nam SW, Clair T, Kim YS, McMarlin A, Schiffmann E, Liotta LA \& Stracke ML 2001 Autotaxin (NPP-2), a metastasis-enhancing motogen, is an angiogenic factor. Cancer Research 61 6938-6944.

Nelson J, Bagnato A, Battistini B \& Nisen P 2003a The endothelin axis: emerging role in cancer. Nature Reviews Cancer 3 110-116.

Nelson JB, Nabulsi AA, Vogelzang NJ, Breul J, Zonnenberg BA, Daliani DD, Schulman CC \& Carducci MA 2003b Suppression of prostate cancer induced bone remodeling by the endothelin receptor A antagonist atrasentan. Journal of Urology 169 1143-1149.

Nemeth EF 2002 Pharmacological regulation of parathyroid hormone secretion. Current Pharmaceutical Design 8 2077-2087.

Nielsen PK, Rasmussen AK, Feldt-Rasmussen U, Brandt M, Christensen L \& Olgaard K 1996 Ectopic production of 
intact parathyroid hormone by a squamous cell lung carcinoma in vivo and in vitro. Journal of Clinical Endocrinology and Metabolism 81 3793-3796.

Norman AW, Roth J \& Orci L 1982 The vitamin D endocrine system: steroid metabolism, hormone receptors, and biological response (calcium binding proteins). Endocrine Reviews 3 331-366.

Nussbaum SR, Gaz RD \& Arnold A 1990 Hypercalcemia and ectopic secretion of parathyroid hormone by an ovarian carcinoma with rearrangement of the gene for parathyroid hormone. New England Journal of Medicine 323 1324-1328.

Oefelein MG, Ricchiuti V, Conrad W \& Resnick MI 2002 Skeletal fractures negatively correlate with overall survival in men with prostate cancer. Journal of Urology 168 1005-1007.

Oehler MK, Rees MC \& Bicknell R 2000 Steroids and the endometrium. Current Medicinal Chemistry 7 543-560.

Okazaki T, Igarashi T \& Kronenberg HM 1988 5'-flanking region of the parathyroid hormone gene mediates negative regulation by $1,25-(\mathrm{OH}) 2$ vitamin D3. Journal of Biological Chemistry 263 2203-2208.

Orr W, Varani J, Gondex MK, Ward PA \& Mundy GR 1979 Chemotactic responses of tumor cells to products of resorbing bone. Science 203 176-179.

Paling MR \& Pope TL 1988 Computed tomography of isolated osteoblastic colon metastases in the bony pelvis. Journal of Computed Tomography 12 203-207.

Parsons SJ \& Parsons JT 2004 Src family kinases, key regulators of signal transduction. Oncogene 23 7906-7909.

Pederson RT, Haidak DJ, Ferris RA, Macdonald JS \& Schein PS 1976 Osteoblastic bone metastasis in Zollinger-Ellison syndrome. Radiology 118 63-64.

Pfeilschifter J \& Mundy GR 1987 Modulation of type beta transforming growth factor activity in bone cultures by osteotropic hormones. PNAS 84 2024-2028.

Philbrick WM, Dreyer BE, Nakchbandi IA \& Karaplis AC 1998 Parathyroid hormone-related protein is required for tooth eruption. PNAS 95 11846-11851.

Pingi A, Trasimeni G, Di Biasi C, Gualdi G, Piazza G, Corsi F \& Chiappetta F 1995 Diffuse leptomeningeal gliomatosis with osteoblastic metastases and no evidence of intraaxial lesions. American Journal of Neuroradiology 16 1018-1020.

Pirola CJ, Wang HM, Strgacich MI, Kamyar A, Cercek B, Forrester JS, Clemens TL \& Fagin JA 1994 Mechanical stimuli induce vascular parathyroid hormone-related protein gene expression in vivo and in vitro. Endocrinology 134 2230-2236.

Plawner LL, Philbrick WM, Burtis WJ, Broadus AE \& Stewart AF 1995 Cell type-specific secretion of parathyroid hormone-related protein via the regulated versus the constitutive secretory pathway. Journal of Biological Chemistry 270 14078-14084.

Playford MP \& Schaller MD 2004 The interplay between Src and integrins in normal and tumor biology. Oncogene $\mathbf{2 3}$ 7928-7946.
Plotkin LI, Weinstein RS, Parfitt AM, Roberson PK, Manolagas SC \& Bellido T 1999 Prevention of osteocyte and osteoblast apoptosis by bisphosphonates and calcitonin. Journal of Clinical Investigation 104 1363-1374. van der Pluijm G, Vloedgraven $H$, van Beek E, van der Wee-Pals L, Lowik C \& Papapoulos S 1996 Bisphosphonates inhibit the adhesion of breast cancer cells to bone matrices in vitro. Journal of Clinical Investigation 98 698-705.

van der Pluijm G, Lowik C \& Papapoulos S 2000 Tumour progression and angiogenesis in bone metastasis from breast cancer: new approaches to an old problem. Cancer Treatment Reviews 26 11-27.

Portale AA, Halloran BP \& Morris RC Jr 1989 Physiologic regulation of the serum concentration of 1,25dihydroxyvitamin D by phosphorus in normal men. Journal of Clinical Investigation 83 1494-1499.

Powell GJ, Southby J, Danks JA, Stillwell RG, Hayman JA, Henderson MA, Bennett RC \& Martin TJ 1991 Localization of parathyroid hormone-related protein in breast cancer metastases: increased incidence in bone compared with other sites. Cancer Research 51 3059-3061.

Powles TJ, Clark SA, Easty DM, Easty GC \& Neville AM 1973 The inhibition by aspirin and indomethacin of osteolytic tumor deposits and hypercalcaemia in rats with Walker tumour, and its possible application to human breast cancer. British Journal of Cancer $\mathbf{2 8}$ 316-321.

Powles T, Paterson S, Kanis JA, McCloskey E, Ashley S, Tidy A, Rosenquist K, Smith I, Ottestad L, Legault S et al. 2002 Randomized, placebo-controlled trial of clodronate in patients with primary operable breast cancer. Journal of Clinical Oncology 20 3219-3224.

Purohit OP, Radstone CR, Anthony C, Kanis JA \& Coleman RE 1995 A randomised double-blind comparison of intravenous pamidronate and clodronate in the hypercalcaemia of malignancy. British Journal of Cancer 72 1289-1293.

Pyrhonen S, Ellmen J, Vuorinen J, Gershanovich M, Tominaga T, Kaufmann M \& Hayes DF 1999 Metaanalysis of trials comparing toremifene with tamoxifen and factors predicting outcome of antiestrogen therapy in postmenopausal women with breast cancer. Breast Cancer Research and Treatment 56 133-143.

Quilty PM, Kirk D, Bolger JJ, Dearnaley DP, Lewington VJ, Mason MD, Reed NS, Russell JM \& Yardley J 1994 A comparison of the palliative effects of strontium-89 and external beam radiotherapy in metastatic prostate cancer. Radiotherapy and Oncology 31 33-40.

Rahme E, Barkun AN, Toubouti Y \& Bardou M 2003 The cyclooxygenase-2-selective inhibitors rofecoxib and celecoxib prevent colorectal neoplasia occurrence and recurrence (Comment). Gastroenterology 125 404-412.

Ralston SH, Gallacher SJ, Patel U, Campbell J \& Boyle IT 1990 Cancer-associated hypercalcemia: morbidity and mortality. Clinical experience in 126 treated patients (Comment). Annals of Internal Medicine 112 499-504. 
Ranuncolo SM, Armanasco E, Cresta C, Bal De Kier Joffe E \& Puricelli L 2003 Plasma MMP-9 (92 kDa-MMP) activity is useful in the follow-up and in the assessment of prognosis in breast cancer patients. International Journal of Cancer 106 745-751.

Reddy SV \& Roodman GD 1998 Control of osteoclast differentiation. Critical Reviews in Eukaryotic Gene Expression 8 1-17.

Reinholz GG, Getz B, Pederson L, Sanders ES, Subramaniam M, Ingle JN \& Spelsberg TC 2000 Bisphosphonates directly regulate cell proliferation, differentiation, and gene expression in human osteoblasts. Cancer Research 60 6001-6007.

Remuzzi G, Perico N \& Benigni A 2002 New therapeutics that antagonize endothelin: promises and frustrations. Nature Reviews Drug Discovery 1 986-1001.

Rizzoli R, Pache JC, Didierjean L, Burger A \& Bonjour JP 1994 A thymoma as a cause of true ectopic hyperparathyroidism. Journal of Clinical Endocrinology and Metabolism 79 912-915.

Rolli M, Fransvea E, Pilch J, Saven A \& Felding-Habermann B 2003 Activated integrin alphavbeta3 cooperates with metalloproteinase MMP-9 in regulating migration of metastatic breast cancer cells. PNAS 100 9482-9487.

Roodman GD 2003 Role of stromal-derived cytokines and growth factors in bone metastasis. Cancer 97 733-738.

Rosen LS, Gordon D, Tchekmedyian S, Yanagihara R, Hirsh V, Krzakowski M, Pawlicki M, de Souza P, Zheng M, Urbanowitz G et al. 2003 Zoledronic acid versus placebo in the treatment of skeletal metastases in patients with lung cancer and other solid tumors: a phase III, double-blind, randomized trial - the Zoledronic Acid Lung Cancer and Other Solid Tumors Study Group. Journal of Clinical Oncology 21 3150-3157.

Rosenbaum E \& Carducci MA 2003 Pharmacotherapy of hormone refractory prostate cancer: new developments and challenges. Expert Opinion on Pharmacotherapy 4 875-887.

Rosenthal N, Insogna KL, Godsall JW, Smaldone L, Waldron JA \& Stewart AF 1985 Elevations in circulating 1,25-dihydroxyvitamin $\mathrm{D}$ in three patients with lymphoma-associated hypercalcemia. Journal of Clinical Endocrinology and Metabolism 60 29-33.

Roy F \& Mareel M 1992 Tumour invasion: effects of cell adhesion and motility. Trends in Cell Biology 2 163-169.

Saad F, Gleason DM, Murray R, Tchekmedyian S, Venner P, Lacombe L, Chin JL, Vinholes JJ, Goas JA \& Chen B 2002 A randomized, placebo-controlled trial of zoledronic acid in patients with hormone-refractory metastatic prostate carcinoma. Journal of the National Cancer Institute 94 1458-1468.

Sabatini M, Boyce B, Aufdemorte T, Bonewald L \& Mundy GR 1988 Infusions of recombinant human interleukins 1 alpha and 1 beta cause hypercalcemia in normal mice. PNAS 85 5235-5239.

Sabino MA, Ghilardi JR, Jongen JL, Keyser CP, Luger NM, Mach DB, Peters CM, Rogers SD, Schwei MJ, de
Felipe C et al. 2002 Simultaneous reduction in cancer pain, bone destruction, and tumor growth by selective inhibition of cyclooxygenase-2. Cancer Research 62 7343-7349.

Sachdev D \& Yee D 2001 The IGF system and breast cancer. Endocrine-Related Cancer 8 197-209.

Safadi FF, Xu J, Smock SL, Kanaan RA, Selim AH, Odgren PR, Marks SC Jr, Owen TA \& Popoff SN 2003 Expression of connective tissue growth factor in bone: its role in osteoblast proliferation and differentiation in vitro and bone formation in vivo. Journal of Cellular Physiology 196 51-62.

Sanders JL, Chattopadhyay N, Kifor O, Yamaguchi T, Butters RR \& Brown EM 2000 Extracellular calciumsensing receptor expression and its potential role in regulating parathyroid hormone-related peptide secretion in human breast cancer cell lines. Endocrinology 141 4357-4364.

Schilling T, Pecherstorfer M, Blind E, Leidig G, Ziegler R \& Raue F 1993 Parathyroid hormone-related protein (PTHrP) does not regulate 1,25-dihydroxyvitamin D serum levels in hypercalcemia of malignancy. Journal of Clinical Endocrinology and Metabolism 76 801-803.

Schluter KD \& Piper HM 1998 Cardiovascular actions of parathyroid hormone and parathyroid hormonerelated peptide. (Comment). Cardiovascular Research $3734-41$.

Schluter KD, Katzer C \& Piper HM 2001 A N-terminal PTHrP peptide fragment void of a PTH/PTHrP-receptor binding domain activates cardiac ET(A) receptors. British Journal of Pharmacology 132 427-432.

Senaratne SG, Pirianov G, Mansi JL, Arnett TR \& Colston KW 2000 Bisphosphonates induce apoptosis in human breast cancer cell lines. British Journal of Cancer 82 1459-1468.

Serafini AN 2000 Samarium Sm-153 lexidronam for the palliation of bone pain associated with metastases. Cancer 88 2934-2939.

Seymour JF, Grill V, Martin TJ, Lee N \& Firkin F 1993 Hypercalcemia in the blastic phase of chronic myeloid leukemia associated with elevated parathyroid hormonerelated protein. Leukemia 7 1672-1675.

Seymour JF, Gagel RF, Hagemeister FB, Dimopoulos MA \& Cabanillas F 1994 Calcitriol production in hypercalcemic and normocalcemic patients with nonHodgkin lymphoma (Comment). Annals of Internal Medicine 121 633-640.

Shevrin DH, Kukreja SC, Ghosh L \& Lad TE 1988 Development of skeletal metastasis by human prostate cancer in athymic nude mice. Clinical and Experimental Metastasis 6 401-409.

Silletti S, Paku S \& Raz A 1996 Tumor autocrine motility factor responses are mediated through cell contact and focal adhesion rearrangement in the absence of new tyrosine phosphorylation in metastatic cells. American Journal of Pathology 148 1649-1660. 
Silver J, Naveh-Many T, Mayer H, Schmelzer HJ \& Popovtzer MM 1986 Regulation by vitamin D metabolites of parathyroid hormone gene transcription in vivo in the rat. Journal of Clinical Investigation $\mathbf{7 8}$ 1296-1301.

Simonet WS, Lacey DL, Dunstan CR, Kelley M, Chang MS, Luthy R, Nguyen HQ, Wooden S, Bennett L, Boone T et al. 1997 Osteoprotegerin: a novel secreted protein involved in the regulation of bone density (Comment). Cell 89 309-319.

Singer FR, Ritch PS, Lad TE, Ringenberg QS, Schiller JH, Recker RR \& Ryzen E 1991 Treatment of hypercalcemia of malignancy with intravenous etidronate. A controlled, multicenter study. The Hypercalcemia Study Group (Comment). (Erratum appears in Archives of Internal Medicine 1991151 2008). Archives of Internal Medicine 151 471-476.

Smith MR, Eastham J, Gleason DM, Shasha D, Tchekmedyian S \& Zinner N 2003 Randomized controlled trial of zoledronic acid to prevent bone loss in men receiving androgen deprivation therapy for nonmetastatic prostate cancer. Journal of Urology 169 2008-2012.

Southby J, Kissin MW, Danks JA, Hayman JA, Moseley JM, Henderson MA, Bennett RC \& Martin TJ 1990 Immunohistochemical localization of parathyroid hormone-related protein in human breast cancer. Cancer Research 50 7710-7716.

Sparks N, Gizachew K, Tennessee S, Richman L, Tice D, An LL, Mao SY \& Heinrichs JH 2003 Vitaxin, a humanized-monoclonal antibody targeting alpha-v beta3 , inhibits binding and migration of tumor cells to bone matrix proteins and increases survival in a mouse model of bone metastases. Proceedings of the IVth International Conference on Cancer-Induced Bone Diseases, Paget Foundation, San Antonio, TX, USA.

Spuentrup E, Buecker A, Adam G, van Vaals JJ \& Guenther RW 2001 Diffusion-weighted MR imaging for differentiation of benign fracture edema and tumor infiltration of the vertebral body. American Journal of Roentgenology 176 351-358.

Stamenkovic I 2003 Extracellular matrix remodelling: the role of matrix metalloproteinases. Journal of Pathology $200448-464$.

Stewart AF, Horst R, Deftos LJ, Cadman EC, Lang R \& Broadus AE 1980 Biochemical evaluation of patients with cancer-associated hypercalcemia: evidence for humoral and nonhumoral groups. New England Journal of Medicine 303 1377-1383.

Stewart AF, Vignery A, Silverglate A, Ravin ND, LiVolsi V, Broadus AE \& Baron R 1982 Quantitative bone histomorphometry in humoral hypercalcemia of malignancy: uncoupling of bone cell activity. Journal of Clinical Endocrinology and Metabolism 55 219-227.

Strewler GJ, Stern PH, Jacobs JW, Eveloff J, Klein RF, Leung SC, Rosenblatt M \& Nissenson RA 1987 Parathyroid hormonelike protein from human renal carcinoma cells. Structural and functional homology with parathyroid hormone. Journal of Clinical Investigation 80 1803-1807.

Strewler GJ, Budayr AA, Clark OH \& Nissenson RA 1993 Production of parathyroid hormone by a malignant nonparathyroid tumor in a hypercalcemic patient. Journal of Clinical Endocrinology and Metabolism 76 1373-1375.

Suda T, Takahashi N \& Martin TJ 1992 Modulation of osteoclast differentiation. Endocrine Reviews 13 66-80.

Suki WN, Yium JJ, Von Minden M, Saller-Hebert C, Eknoyan G \& Martinez-Maldonado M 1970 Acute treatment of hypercalcemia with furosemide. New England Journal of Medicine 283 836-840.

Sung V, Stubbs JT 3rd, Fisher L, Aaron AD \& Thompson EW 1998 Bone sialoprotein supports breast cancer cell adhesion proliferation and migration through differential usage of the alpha(v)beta3 and alpha(v)beta5 integrins. Journal of Cellular Physiology 176 482-494.

Suva LJ, Winslow GA, Wettenhall RE, Hammonds RG, Moseley JM, Diefenbach-Jagger H, Rodda CP, Kemp BE, Rodriguez H, Chen EY et al. 1987 A parathyroid hormone-related protein implicated in malignant hypercalcemia: cloning and expression. Science $\mathbf{2 3 7}$ 893-896.

Swarthout JT, D'Alonzo RC, Selvamurugan N \& Partridge NC 2002 Parathyroid hormone-dependent signaling pathways regulating genes in bone cells. Gene $2821-17$.

Taichman RS, Cooper C, Keller ET, Pienta KJ, Taichman NS \& McCauley LK 2002 Use of the stromal cell-derived factor-1/CXCR4 pathway in prostate cancer metastasis to bone. Cancer Research 62 1832-1837.

Takahashi N, Yamana H, Yoshiki S, Roodman GD, Mundy GR, Jones SJ, Boyde A \& Suda T 1988 Osteoclast-like cell formation and its regulation by osteotropic hormones in mouse bone marrow cultures. Endocrinology 122 1373-1382.

Takeyama K, Kitanaka S, Sato T, Kobori M, Yanagisawa J \& Kato S 1997 25-Hydroxyvitamin D3 1alphahydroxylase and vitamin D synthesis. Science $\mathbf{2 7 7}$ 1827-1830.

Talukder AH, Adam L, Raz A \& Kumar R 2000 Heregulin regulation of autocrine motility factor expression in human tumor cells. Cancer Research 60 474-480.

Tatsumi S, Segawa H, Morita K, Haga H, Kouda T, Yamamoto H, Inoue Y, Nii T, Katai K, Taketani Y et al. 1998 Molecular cloning and hormonal regulation of PiT-1, a sodium-dependent phosphate cotransporter from rat parathyroid glands. Endocrinology 139 1692-1699.

Taube T, Elomaa I, Blomqvist C, Beneton MN \& Kanis JA 1994 Histomorphometric evidence for osteoclastmediated bone resorption in metastatic breast cancer. Bone 15 161-166.

Thiebaud D, Jacquet AF \& Burckhardt P 1990 Fast and effective treatment of malignant hypercalcemia. 
Combination of suppositories of calcitonin and a single infusion of 3-amino 1-hydroxypropylidene-1bisphosphonate. Archives of Internal Medicine $\mathbf{1 5 0}$ 2125-2128.

Thiede MA, Daifotis AG, Weir EC, Brines ML, Burtis WJ, Ikeda K, Dreyer BE, Garfield RE \& Broadus AE 1990 Intrauterine occupancy controls expression of the parathyroid hormone-related peptide gene in preterm rat myometrium. PNAS 87 6969-6973.

Thomas RJ, Guise TA, Yin JJ, Elliott J, Horwood NJ, Martin TJ \& Gillespie MT 1999 Breast cancer cells interact with osteoblasts to support osteoclast formation. Endocrinology 140 4451-4458.

Thun MJ, Namboodiri MM \& Heath CW Jr 1991 Aspirin use and reduced risk of fatal colon cancer (Comment). New England Journal of Medicine 325 1593-1596.

Tokuda H, Kozawa O, Harada A \& Uematsu T 1998 Tiludronate inhibits interleukin-6 synthesis in osteoblasts: inhibition of phospholipase D activation in MC3T3-E1 cells. Journal of Cellular Biochemistry 69 252-259.

Tong D, Gillick L \& Hendrickson FR 1982 The palliation of symptomatic osseous metastases: final results of the study by the Radiation Therapy Oncology Group. Cancer 50 893-899.

Tucker GC 2003 Alpha v integrin inhibitors and cancer therapy. Current Opinion in Investigational Drugs 4 $722-731$.

Tuttle KR, Kunau RT, Loveridge N \& Mundy GR 1991 Altered renal calcium handling in hypercalcemia of malignancy. Journal of the American Society of Nephrology 2 191-199.

Ueno M, Ban S, Nakanoma T, Tsukamoto T, Nonaka S, Hirata R, Iida M \& Deguchi N 2000 Hypercalcemia in a patient with renal cell carcinoma producing parathyroid hormone-related protein and interleukin-6. International Journal of Urology 7 239-242.

Upadhyay J, Shekarriz B, Nemeth JA, Dong Z, Cummings GD, Fridman R, Sakr W, Grignon DJ \& Cher ML 1999 Membrane type 1-matrix metalloproteinase (MT1-MMP) and MMP-2 immunolocalization in human prostate: change in cellular localization associated with high-grade prostatic intraepithelial neoplasia. Clinical Cancer Research 5 4105-4110.

van der Pluijm G, Sijmons B, Vloedgraven H, Deckers M, Papapoulos S \& Lowik C 2001 Monitoring metastatic behavior of human tumor cells in mice with speciesspecific polymerase chain reaction: elevated expression of angiogenesis and bone resorption stimulators by breast cancer in bone metastases. Journal of Bone \& Mineral Research 16 1077-1091.

Vargas SJ, Gillespie MT, Powell GJ, Southby J, Danks JA, Moseley JM \& Martin TJ 1992 Localization of parathyroid hormone-related protein mRNA expression in breast cancer and metastatic lesions by in situ hybridization. Journal of Bone and Mineral Research 7 971-979.

van't Veer LJ, Dai H, van de Vijver MJ, He YD, Hart AA, Mao M, Peterse HL, van der Kooy K, Marton MJ,
Witteveen AT et al. 2002 Gene expression profiling predicts clinical outcome of breast cancer. Nature 415 530-536.

Verbeek BS, Vroom TM, Adriaansen-Slot SS, OttenhoffKalff AE, Geertzema JG, Hennipman A \& Rijksen G $1996 \mathrm{c}-\mathrm{Src}$ protein expression is increased in human breast cancer. An immunohistochemical and biochemical analysis. Journal of Pathology 180 383-388.

Viereck V, Emons G, Lauck V, Frosch KH, Blaschke S, Grundker C \& Hofbauer LC 2002 Bisphosphonates pamidronate and zoledronic acid stimulate osteoprotegerin production by primary human osteoblasts. Biochemical \& Biophysical Research Communications 291 680-686.

Virtanen SS, Vaananen HK, Harkonen PL \& Lakkakorpi PT 2002 Alendronate inhibits invasion of PC-3 prostate cancer cells by affecting the mevalonate pathway. Cancer Research 62 2708-2714.

Wada S, Yasuda S, Nagai T, Maeda T, Kitahama S, Suda S, Findlay DM, Iitaka M \& Katayama S 2001 Regulation of calcitonin receptor by glucocorticoid in human osteoclast-like cells prepared in vitro using receptor activator of nuclear factor-kappaB ligand and macrophage colony-stimulating factor. Endocrinology 142 1471-1478.

Watanabe H, Carmi P, Hogan V, Raz T, Silletti S, Nabi IR \& Raz A 1991 Purification of human tumor cell autocrine motility factor and molecular cloning of its receptor. Journal of Biological Chemistry 266 13442-13448.

Watanabe H, Takehana K, Date M, Shinozaki T \& Raz A 1996 Tumor cell autocrine motility factor is the neuroleukin/phosphohexose isomerase polypeptide. Cancer Research 56 2960-2963.

Weissglas M, Schamhart D, Lowik C, Papapoulos S, Vos P \& Kurth KH 1995 Hypercalcemia and cosecretion of interleukin-6 and parathyroid hormone related peptide by a human renal cell carcinoma implanted into nude mice. Journal of Urology 153 854-857.

Wieser R, Attisano L, Wrana JL \& Massague J 1993 Signaling activity of transforming growth factor beta type II receptors lacking specific domains in the cytoplasmic region. Molecular and Cellular Biology 13 7239-7247.

Wieser R, Wrana JL \& Massague J 1995 GS domain mutations that constitutively activate $\mathrm{T}$ beta R-I, the downstream signaling component in the TGF-beta receptor complex. EMBO Journal 14 2199-2208.

Wimalawansa SJ 1994 Significance of plasma PTH-rp in patients with hypercalcemia of malignancy treated with bisphosphonate. Cancer 73 2223-2230.

Wood J, Bonjean K, Ruetz S, Bellahcene A, Devy L, Foidart JM, Castronovo V \& Green JR 2002 Novel antiangiogenic effects of the bisphosphonate compound zoledronic acid. Journal of Pharmacology and Experimental Therapeutics 302 1055-1061.

Wrana JL, Attisano L, Wieser R, Ventura F \& Massague J 1994 Mechanism of activation of the TGF-beta receptor. Nature 370 341-347. 
Wu JS, Wong R, Johnston M, Bezjak A \& Whelan T 2003 Meta-analysis of dose-fractionation radiotherapy trials for the palliation of painful bone metastases. International Journal of Radiation Oncology-Biology-Physics 55 594-605.

Wysolmerski JJ, Carucci JM, Broadus AE \& Philbrick WM $1994 a$ PTH and PTHrP antagonize mammary gland growth and development in transgenic mice. Journal of Bone and Mineral Research $9 \mathrm{~S} 121$.

Wysolmerski JJ, Broadus AE, Zhou J, Fuchs E, Milstone LM \& Philbrick WM 1994b Overexpression of parathyroid hormone-related protein in the skin of transgenic mice interferes with hair follicle development. PNAS 91 1133-1137.

Wysolmerski JJ, Philbrick WM, Dunbar ME, Lanske B, Kronenberg H \& Broadus AE 1998 Rescue of the parathyroid hormone-related protein knockout mouse demonstrates that parathyroid hormone-related protein is essential for mammary gland development. Development 125 1285-1294.

Wysolmerski JJ, Dann PR, Zelazny E, Dunbar ME, Insogna KL, Guise TA \& Perkins AS 2002 Overexpression of parathyroid hormone-related protein causes hypercalcemia but not bone metastases in a murine model of mammary tumorigenesis. Journal of Bone and Mineral Research 17 1164-1170.

Yamaguchi T, Chattopadhyay N \& Brown EM 2000 G protein-coupled extracellular $\mathrm{Ca} 2+(\mathrm{Ca} 2+\mathrm{o})$-sensing receptor $(\mathrm{CaR})$ : roles in cell signaling and control of diverse cellular functions. Advances in Pharmacology 47 209-253.

Yamamoto M, Harm SC, Grasser WA \& Thiede MA 1992 Parathyroid hormone-related protein in the rat urinary bladder: a smooth muscle relaxant produced locally in response to mechanical stretch. PNAS 89 5326-5330.

Yasuda H, Shima N, Nakagawa N, Mochizuki SI, Yano K, Fujise N, Sato Y, Goto M, Yamaguchi K, Kuriyama M et al. 1998 Identity of osteoclastogenesis inhibitory factor (OCIF) and osteoprotegerin (OPG): a mechanism by which OPG/OCIF inhibits osteoclastogenesis in vitro. Endocrinology 139 1329-1337.

Yates AJ, Boyce BF, Favarato G, Aufdemorte TB, Marcelli C, Kester MB, Walker R, Langton BC, Bonewald LF \& Mundy GR 1992 Expression of human transforming growth factor alpha by Chinese hamster ovarian tumors in nude mice causes hypercalcemia and increased osteoclastic bone resorption. Journal of Bone and Mineral Research 7 847-853.

Yi B, Williams PJ, Niewolna M, Wang Y \& Yoneda T 2002 Tumor-derived platelet-derived growth factor-BB plays a critical role in osteosclerotic bone metastasis in an animal model of human breast cancer. Cancer Research 62 917-923.

Yin JJ, Taylor SD, Yoneda T, Dallas M, Boyce BF, Kumagai Y, Mundy GR \& Guise TA 1995 Evidence that parathyroid hormone-related protein (PTHrP) cause osteolytic metastases without hypercalcemia. Journal of Bone and Mineral Research 10 S169.

Yin JJ, Selander K, Chirgwin JM, Dallas M, Grubbs BG, Wieser R, Massague J, Mundy GR \& Guise TA 1999 TGF-beta signaling blockade inhibits PTHrP secretion by breast cancer cells and bone metastases development. Journal of Clinical Investigation 103 197-206.

Yin JJ, Mohammad KS, Kakonen SM, Harris S, Wu-Wong JR, Wessale JL, Padley RJ, Garrett IR, Chirgwin JM \& Guise TA 2003 A causal role for endothelin-1 in the pathogenesis of osteoblastic bone metastases. PNAS 100 10954-10959.

Yoneda T 1996 Mechanisms of preferential metastasis of breast cancer to bone. International Journal of Oncology 9 103-109.

Yoneda T 2000 Cellular and molecular basis of preferential metastasis of breast cancer to bone. Journal of Orthopaedic Science 5 75-81.

Yoneda T, Sasaki A, Dunstan C, Williams PJ, Bauss F, De Clerck YA \& Mundy GR 1997 Inhibition of osteolytic bone metastasis of breast cancer by combined treatment with the bisphosphonate ibandronate and tissue inhibitor of the matrix metalloproteinase-2. Journal of Clinical Investigation 99 2509-2517.

Yoneda T, Williams PJ, Hiraga T, Niewolna M \& Nishimura R 2001 A bone-seeking clone exhibits different biological properties from the MDA-MB-231 parental human breast cancer cells and a brain-seeking clone in vivo and in vitro. Journal of Bone and Mineral Research $\mathbf{1 6}$ 1486-1495.

Yoshimoto K, Yamasaki R, Sakai H, Tezuka U, Takahashi M, Iizuka M, Sekiya T \& Saito S 1989 Ectopic production of parathyroid hormone by small cell lung cancer in a patient with hypercalcemia. Journal of Clinical Endocrinology and Metabolism 68 976-981.

Young RF, Post EM \& King GA 1980 Treatment of spinal epidural metastases. Randomized prospective comparison of laminectomy and radiotherapy. Journal of Neurosurgery 53 741-748.

Zakalik D, Diep D, Hooks MA, Nissenson RA \& Strewler GJ 1992 Tranforming growth factor-beta increases stability of parathyroid hormone-related protein messenger RNA. Journal of Bone and Mineral Research $7 \mathrm{~S} 118$

Zehnder D, Bland R, Williams MC, McNinch RW, Howie AJ, Stewart PM \& Hewison M 2001 Extrarenal expression of 25-hydroxyvitamin d(3)-1 alphahydroxylase. Journal of Clinical Endocrinology and Metabolism 86 888-894.

Zerwekh JE \& Breslau NA 1986 Human placental production of 1 alpha,25-dihydroxyvitamin D3: biochemical characterization and production in normal subjects and patients with pseudohypoparathyroidism. Journal of Clinical Endocrinology and Metabolism 62 192-196.

Zudaire E, Martinez A \& Cuttitta F 2003 Adrenomedullin and cancer. Regulatory Peptides 112 175-183. 
